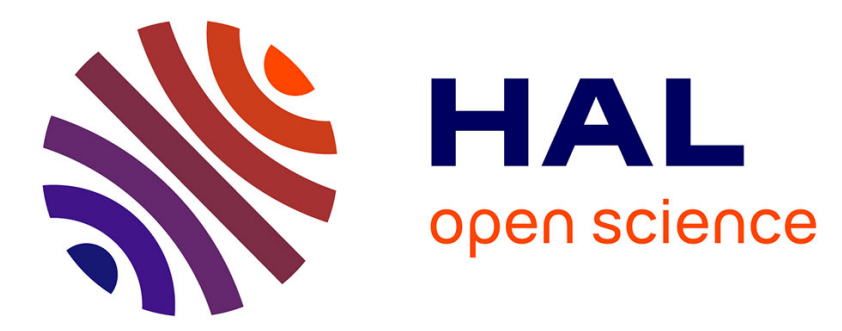

\title{
Polymorphism of even saturated carboxylic acids from n-decanoic to n-eicosanoic acid
}

Evelyn Moreno-Calvo, Raquel Cordobilla, Teresa Calvet, Miquel Angel Cuevas-Diarte, Gabin Gbabode, Philippe Négrier, Denise Mondieig, Harry A. J. Oonk

\section{To cite this version:}

Evelyn Moreno-Calvo, Raquel Cordobilla, Teresa Calvet, Miquel Angel Cuevas-Diarte, Gabin Gbabode, et al.. Polymorphism of even saturated carboxylic acids from n-decanoic to n-eicosanoic acid. New Journal of Chemistry, 2007, 31 (6), pp.947-957. 10.1039/b700551b . hal-01553018

\section{HAL Id: hal-01553018 https://hal.science/hal-01553018}

Submitted on 24 Jul 2017

HAL is a multi-disciplinary open access archive for the deposit and dissemination of scientific research documents, whether they are published or not. The documents may come from teaching and research institutions in France or abroad, or from public or private research centers.
L'archive ouverte pluridisciplinaire HAL, est destinée au dépôt et à la diffusion de documents scientifiques de niveau recherche, publiés ou non, émanant des établissements d'enseignement et de recherche français ou étrangers, des laboratoires publics ou privés. 


\title{
Polymorphism of even saturated carboxylic acids from $n$-decanoic to n-eicosanoic acid
}

\author{
Evelyn Moreno, ${ }^{a}$ Raquel Cordobilla, ${ }^{a}$ Teresa Calvet, ${ }^{* a}$ M. A. Cuevas-Diarte, ${ }^{a}$ \\ Gabin Gbabode, ${ }^{b}$ Philippe Negrier, $^{b}$ Denise Mondieig ${ }^{b}$ and Harry A. J. Oonk ${ }^{c}$
}

The polymorphism of normal saturated even carboxylic acids from $n$ decanoic to $n$ eicosanoic acid is discussed. Seven crystal modifications, including polymorphs and polytypes, were identified and fully characterized by the combination of calorimetric measurements (DSC) at atmospheric and high pressures, X ray powder diffraction, FT IR spectroscopy and scanning electron microscopy (SEM). All seven crystal forms, including polymorphs and polytypes, are observed at room temperature. Forms $\mathrm{A}_{2}$ and $\mathrm{A}_{\text {super }}$ are triclinic, form $\mathrm{C}$ is monoclinic and forms $\mathrm{E}$ and $\mathrm{B}$ show both a monoclinic and an orthorhombic polytype. The triclinic modifications $\mathrm{A}_{2}$ and $\mathrm{A}_{\text {super }}$ predominate for acids up to $n$ tetradecanoic acid $\left(\mathrm{C}_{14} \mathrm{H}_{27} \mathrm{O}_{2} \mathrm{H}\right)$. The orthorhombic and the monoclinic forms predominate for acids from $n$ hexadecanoic $\left(\mathrm{C}_{16} \mathrm{H}_{31} \mathrm{O}_{2} \mathrm{H}\right)$ up to $n$ eicosanoic acid $\left(\mathrm{C}_{20} \mathrm{H}_{39} \mathrm{O}_{2} \mathrm{H}\right)$. When the temperature is increased, all the crystal modifications transform irreversibly to the $\mathrm{C}$ form. In the first part of this paper, cell parameters for the different forms are given, the observed temperatures and enthalpies of the transitions are reported and the stability of the different forms is discussed. In the second part, we state the main contribution of each technique for the identification and interpretation of the polymorphism of even numbered carboxylic acids.

\section{Introduction}

This work is the first part of a general study on the family of even saturated $n$ carboxylic acids undertaken within the REALM (Réseau Européen sur les Alliages Moléculaires) group, which works on the elaboration, structural and ther modynamic characterization, modeling, and applications of molecular alloy phase change materials (MAPCM) for energy storage and thermal protection. Previous studies of the $n$ alkane ${ }^{1,2}$ and $n$ alkanol $^{3,4}$ families resulted in several com mercialized industrial applications. ${ }^{5-7}$ That encouraged us to undertake the study of the family of $n$ carboxylic acids, beginning with a polymorphism comprehension, since they are substances with high enthalpies of melting and, thus, promising candidates for the design of new MAPCMs.

The polymorphism of carboxylic acids has been discussed since the fifties but is still a matter of confusion and incom pleteness due to the high number of crystalline forms that exist, the similarity of their structures, the difficulty of obtain ing isolated forms, and the difficulty of growing single crystals of suitable quality for single crystal $\mathrm{X}$ ray diffraction, which

\footnotetext{
${ }^{a}$ Departament de Cristallografia, Mineralogia i Dipósits Minerals, Facultat de Geologia, Universitat de Barcelona, C/ Martí i Franquès s/n,08028 Barcelona, Spain.E mail: mtcalvet@ub.edu; Fax: + 34 93 402 1340; Tel: + 34934021350

${ }^{b}$ Centre de Physique Moléculaire Optique et Hertzienne, UMR 5798 au CNRS Université Bordeaux I, Cours de la Libération 351, 33405 Talence Cedex, France

${ }^{c}$ Chemical Thermodynamics Group, Faculty of Chemistry, Utrecht University, Padualaan 8, NL 3584 CH Utrecht, The Netherlands
}

makes the identification and characterization of the different forms a difficult task. In this paper an account is given of our own systematic investigation on the polymorphism of the even saturated $n$ carboxylic acids, from decanoic to eicosanoic acid, by a complementary approach including $\mathrm{X}$ ray powder dif fraction, differential scanning calorimetry (DSC) at different pressures, Fourier transform infrared spectroscopy (FTIR) and scanning electron microscopy (SEM) techniques.

Normal saturated carboxylic acids with general formula $\mathrm{C}_{n} \mathrm{H}_{2 n-1} \mathrm{O}_{2} \mathrm{H}$ exhibit a rich and complex polymorphic beha viour. The polymorphism of the acids depends on parity, and is a function of temperature. The appearance of a given form is influenced by the temperature and the rate of crystallization, the nature of the solvent, the purity of the acid itself and the number of carbon atoms in the chain.

$\mathrm{A}^{\prime}, \mathrm{B}^{\prime}, \mathrm{C}^{\prime}, \mathrm{C}^{\prime \prime}$ and $\mathrm{D}^{\prime}$ crystal forms are mentioned for carboxylic acids with an odd number of carbon atoms and $\mathrm{A}_{1}, \mathrm{~A}_{2}, \mathrm{~A}_{3}, \mathrm{~A}_{\text {super }}, \mathrm{B}_{\mathrm{o} / \mathrm{m}}, \mathrm{C}$ and $\mathrm{E}_{\mathrm{o} / \mathrm{m}}$ are mentioned for the even numbered ones. ${ }^{8-11}$ In general terms, the packing of these forms consists of bilayers formed by dimers linked together through a typical $\mathrm{R}_{2}^{2}(8)$ hydrogen bond pattern according to graph set notation. ${ }^{12}$ A summary of the structural data reported in the literature is given in Table 1.

The structure of the $\mathrm{C}$ form $^{25,26}\left(P 2_{1} / a, Z \quad\right.$ 4) was determined from in situ crystallization and single crystal experiments. In this crystal form all the molecules in the asymmetric unit adopt an all trans conformation. The dimers are arranged so as to exhibit terminal methyl and terminal carboxyl group monolayers parallel to the $\left(\begin{array}{lll}0 & 0 & 1\end{array}\right)$ plane (Fig. 1). 
Table 1 Bibliographic data for the carboxylic acid structures solved from single crystals

\begin{tabular}{|c|c|c|c|c|}
\hline Phase & Acid & Space group & $Z$ & Ref. \\
\hline$A_{1}$ & $\mathrm{C}_{12} \mathrm{H}_{23} \mathrm{O}_{2} \mathrm{H}$ & Triclinic $P \overline{1}$ & 2 & 13 \\
\hline $\mathrm{A}_{\text {super }}$ & $\mathrm{C}_{12} \mathrm{H}_{23} \mathrm{O}_{2} \mathrm{H}$ & Triclinic $P \overline{1}$ & 6 & 14 \\
\hline $\mathrm{A}^{\prime}$ & $\mathrm{C}_{13} \mathrm{H}_{25} \mathrm{O}_{2} \mathrm{H}$ & Triclinic $P \overline{1}$ & 2 & 15 \\
\hline $\mathrm{A}^{\prime}$ & $\mathrm{C}_{15} \mathrm{H}_{29} \mathrm{O}_{2} \mathrm{H}$ & Triclinic $P \overline{1}$ & 2 & 16,17 \\
\hline $\mathrm{B}^{\prime}$ & $\mathrm{C}_{15} \mathrm{H}_{29} \mathrm{O}_{2} \mathrm{H}$ & Triclinic $P \overline{1}$ & 4 & 18 \\
\hline $\mathrm{B}^{\prime}$ & $\mathrm{C}_{17} \mathrm{H}_{33} \mathrm{O}_{2} \mathrm{H}$ & Triclinic $P \overline{1}$ & 4 & 19 \\
\hline $\mathrm{B}^{\prime}$ & $\mathrm{C}_{19} \mathrm{H}_{37} \mathrm{O}_{2} \mathrm{H}$ & Triclinic $P \overline{1}$ & 4 & 20 \\
\hline $\mathrm{B}_{\mathrm{m}}$ & $\mathrm{C}_{18} \mathrm{H}_{35} \mathrm{O}_{2} \mathrm{H}$ & Monoclinic $P 2_{1} / a$ & 4 & 21 \\
\hline $\mathrm{B}_{\mathrm{o}}$ & $\mathrm{C}_{18} \mathrm{H}_{35} \mathrm{O}_{2} \mathrm{H}$ & Orthorhombic $\mathrm{Pbca}$ & 8 & 22 \\
\hline $\mathrm{E}_{\mathrm{m}}$ & $\mathrm{C}_{18} \mathrm{H}_{35} \mathrm{O}_{2} \mathrm{H}$ & Monoclinic $P 2_{1} / a$ & 4 & 23 \\
\hline $\mathrm{E}_{\mathrm{o}}$ & $\mathrm{C}_{18} \mathrm{H}_{35} \mathrm{O}_{2} \mathrm{H}$ & Orthorhombic $\mathrm{Pbca}$ & 8 & 24 \\
\hline $\mathrm{C}$ & $\mathrm{C}_{6} \mathrm{H}_{11} \mathrm{O}_{2} \mathrm{H}$ & Monoclinic $P 2_{1} / a$ & 4 & $25^{b}$ \\
\hline $\mathrm{C}$ & $\mathrm{C}_{8} \mathrm{H}_{15} \mathrm{O}_{2} \mathrm{H}$ & Monoclinic $P 2_{1} / a$ & 4 & $25^{b}$ \\
\hline $\mathrm{C}$ & $\mathrm{C}_{10} \mathrm{H}_{19} \mathrm{O}_{2} \mathrm{H}$ & Monoclinic $P 2_{1} / a$ & 4 & $25^{b}$ \\
\hline $\mathrm{C}$ & $\mathrm{C}_{12} \mathrm{H}_{23} \mathrm{O}_{2} \mathrm{H}$ & Monoclinic $P 2_{1} / a$ & 4 & $25^{b}$ \\
\hline $\mathrm{C}$ & $\mathrm{C}_{14} \mathrm{H}_{27} \mathrm{O}_{2} \mathrm{H}$ & Monoclinic $P 2_{1} / a$ & 4 & $25^{b}$ \\
\hline $\mathrm{C}$ & $\mathrm{C}_{16} \mathrm{H}_{31} \mathrm{O}_{2} \mathrm{H}$ & Monoclinic $P 2_{1} / a$ & 4 & $26^{b}$ \\
\hline $\mathrm{C}$ & $\mathrm{C}_{18} \mathrm{H}_{35} \mathrm{O}_{2} \mathrm{H}$ & Monoclinic $P 2_{1} / a$ & 4 & $27^{a}$ \\
\hline $\mathrm{C}^{\prime}$ & $\mathrm{C}_{7} \mathrm{H}_{13} \mathrm{O}_{2} \mathrm{H}$ & Monoclinic $P 2_{1} / a$ & 4 & $25^{b}$ \\
\hline $\mathrm{C}^{\prime}$ & $\mathrm{C}_{9} \mathrm{H}_{17} \mathrm{O}_{2} \mathrm{H}$ & Monoclinic $P 2_{1} / a$ & 4 & $25^{b}$ \\
\hline $\mathrm{C}^{\prime}$ & $\mathrm{C}_{11} \mathrm{H}_{21} \mathrm{O}_{2} \mathrm{H}$ & Monoclinic $P 2_{1} / a$ & 4 & $25^{b}$ \\
\hline $\mathrm{C}^{\prime}$ & $\mathrm{C}_{17} \mathrm{H}_{33} \mathrm{O}_{2} \mathrm{H}$ & Monoclinic $P 2_{1} / a$ & 4 & 11 \\
\hline $\mathrm{C}^{\prime}$ & $\mathrm{C}_{19} \mathrm{H}_{37} \mathrm{O}_{2} \mathrm{H}$ & Monoclinic $P 2_{1} / a$ & 4 & 11 \\
\hline $\mathrm{C}^{\prime}$ & $\mathrm{C}_{21} \mathrm{H}_{41} \mathrm{O}_{2} \mathrm{H}$ & Monoclinic $P 2_{1} / a$ & 4 & 11 \\
\hline $\mathrm{C}^{\prime}$ & $\mathrm{C}_{23} \mathrm{H}_{45} \mathrm{O}_{2} \mathrm{H}$ & Monoclinic $P 2_{1} / a$ & 4 & 11 \\
\hline $\mathrm{C}^{\prime \prime}$ & $\mathrm{C}_{13} \mathrm{H}_{25} \mathrm{O}_{2} \mathrm{H}$ & Monoclinic $C 2 / c$ & 8 & 11,2 \\
\hline $\mathrm{C}^{\prime \prime}$ & $\mathrm{C}_{15} \mathrm{H}_{29} \mathrm{O}_{2} \mathrm{H}$ & Monoclinic $C 2 / c$ & 8 & 25,1 \\
\hline
\end{tabular}

${ }^{a}$ Structure solved from powder $\mathrm{X}$ ray diffraction. ${ }^{b}$ Structures origin ally reported in the conventional space group $P 2_{1} / c$.

Crystals of the $\mathrm{B}$ and $\mathrm{E}$ forms observed for $\mathrm{C}_{16} \mathrm{H}_{31} \mathrm{O}_{2} \mathrm{H}$ and $\mathrm{C}_{18} \mathrm{H}_{35} \mathrm{O}_{2} \mathrm{H}$ are indistinguishable by means of their morphol ogy. Structures of the B and E forms (Fig. 2) can be defined as conformational polymorphs: the molecules of the $\mathrm{E}$ form have an all trans conformation whereas the molecules of the $\mathrm{B}$ form adopt a gauche conformation around the $\mathrm{C}_{2} \mathrm{C}_{3}$ bond, as was determined from a spectroscopic study. ${ }^{28}$ The difference in the molecular conformation does not affect significantly the posi tion of the alkyl chains within the layers, the region between the methyl groups being identical in both forms. In addition, the $\mathrm{B}$ and $\mathrm{E}$ crystal forms of $n$ carboxylic acids exhibit polytypism, which arises from a different stacking sequence of the bilayers. A single bilayered monoclinic structure $\left(P 2_{1} / a\right.$, $Z$ 4), indicated with a subscript $m$, and a double bilayered orthorhombic structure (Pbca, $Z$ 8), indicated with a sub script $\mathrm{o}$, were found for the $\mathrm{B}$ and the $\mathrm{E}$ forms of

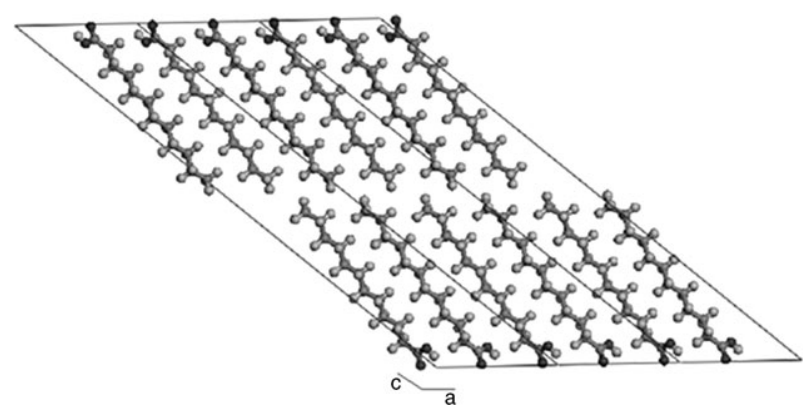

Fig. 1 Crystal packing showing three unit cells of the $\mathrm{C}$ form of $\mathrm{C}_{12} \mathrm{H}_{23} \mathrm{O}_{2} \mathrm{H}^{25}$ represented in the $P 2_{1} / a$ space group.

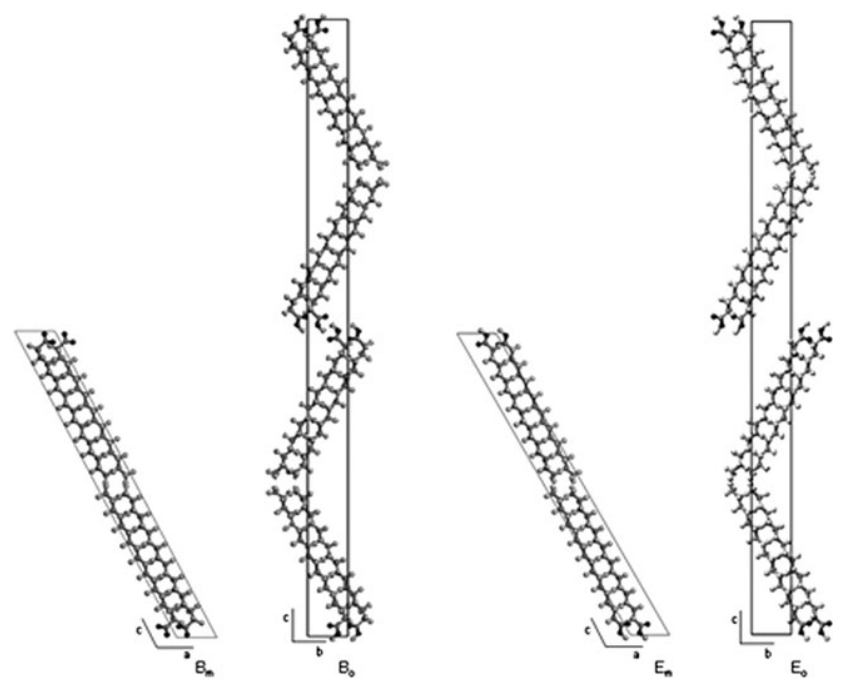

Fig. 2 Crystal packing of the $B_{m}, B_{o}, E_{m}$ and $E_{o}$ (left to right) forms of $\mathrm{C}_{18} \mathrm{H}_{35} \mathrm{O}_{2} \mathrm{H}^{21}{ }^{24}$

$\mathrm{C}_{18} \mathrm{H}_{35} \mathrm{O}_{2} \mathrm{H}^{21-24}$ As in the $\mathrm{C}$ form, the dimers of the $\mathrm{B}$ and $\mathrm{E}$ forms are arranged so as the methyl terminal groups and the carboxyl terminal groups gather in alternating monolayers.

Four different triclinic forms named $\mathrm{A}_{1}, \mathrm{~A}_{2}, \mathrm{~A}_{3}$ and $\mathrm{A}_{\text {super }}$ are vaguely mentioned in the literature. The $A_{\text {super }}$ form has space group $P \overline{1}$ with 6 molecules per unit cell. ${ }^{14}$ However, von Sydow described the $\mathrm{A}_{\text {super }}$ form according to the usual description for long chain hydrogen bonded structures in terms of the chain packing of dimers as $A \overline{1}$ space group, with 12 molecules per unit cell. ${ }^{29}$ The 12 molecules are arranged such that, within a monolayer, three adjacent molecules have their carboxyl groups in one direction, and the next three molecules have their carboxyl groups in the opposite direction. There are two types of molecular conformation in the asym metric unit. In one type, the hydrocarbon chain has an all trans conformation (the plane of the carboxyl group is almost parallel to the plane of the hydrocarbon chain). In the other type, the carboxyl group is rotated along the $\mathrm{C}_{1} \mathrm{C}_{2}$ bond (the plane of the carboxyl group is almost perpendicular to the plane of the hydrocarbon chain). In contrast with the $\mathrm{A}_{\text {super }}$ form, the $\mathrm{A}_{1}$ form of $\mathrm{C}_{12} \mathrm{H}_{23} \mathrm{O}_{2} \mathrm{H}$ described by Lomer has $P \overline{1}$ space group and two molecules per unit cell. ${ }^{13}$ The structure is such that, within a monolayer, the carboxyl group of one molecule is adjacent to the methyl group of the neighbouring molecule (Fig. 3). Thus, in the $\mathrm{A}_{1}(P \overline{1}, Z \quad 2)$ and $\mathrm{A}_{\text {super }}$ $(A \overline{1}, Z \quad 12)$ structures, a given terminal plane contains both methyl and carboxyl groups.

The form $\mathrm{A}_{2}$ was first found by Kobayashi and co workers, who carried out a spectroscopic study on acids $\mathrm{C}_{14} \mathrm{H}_{27} \mathrm{O}_{2} \mathrm{H}$ and $\mathrm{C}_{16} \mathrm{H}_{31} \mathrm{O}_{2} \mathrm{H}^{30}$ They suggested a triclinic cell with sepa rated carboxyl and methyl monolayers and with two types of molecules differing in the conformation of the carboxyl group. In their study they found that, when the temperature is decreased to $140 \mathrm{~K}$, the $\mathrm{A}_{2}$ form changes reversibly into the $\mathrm{A}_{3}$ form. They observed a drastic change in the absorptions associated with the vibrations of the carboxyl group; possibly related to a rearrangement of the hydrogen bonds. To date the 


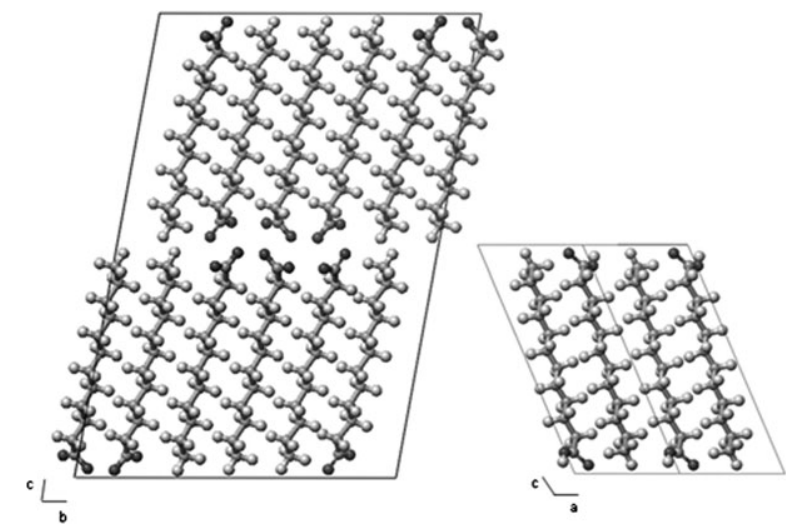

Fig. 3 Crystal packing of (left) the $\mathrm{A}_{\text {super }}{ }^{14}$ and (right) the $\mathrm{A}_{1}{ }^{13}$ (two cells represented) forms of $\mathrm{C}_{12} \mathrm{H}_{23} \mathrm{O}_{2} \mathrm{H}$.

structures of the $A_{2}$ and $A_{3}$ forms have not been solved from single crystal experiments.

\section{Experimental}

\section{Materials}

Samples of $n$ decanoic $\left(\mathrm{C}_{10} \mathrm{H}_{19} \mathrm{O}_{2} \mathrm{H}\right), \quad n$ dodecanoic $\left(\mathrm{C}_{12} \mathrm{H}_{23} \mathrm{O}_{2} \mathrm{H}\right), n$ tetradecanoic $\left(\mathrm{C}_{14} \mathrm{H}_{27} \mathrm{O}_{2} \mathrm{H}\right), n$ hexadecanoic $\left(\mathrm{C}_{16} \mathrm{H}_{31} \mathrm{O}_{2} \mathrm{H}\right), n$ octadecanoic $\left(\mathrm{C}_{18} \mathrm{H}_{35} \mathrm{O}_{2} \mathrm{H}\right)$ and $n$ eicosanoic $\left(\mathrm{C}_{20} \mathrm{H}_{39} \mathrm{O}_{2} \mathrm{H}\right)$ acids were purchased from Fluka and Sigma. Their purity was $\geq 99 \%$ according to GC MS analyses. Experiments were performed on samples of the materials as purchased, on samples prepared by melting and quenching in liquid nitrogen, and on samples obtained from crystallization in pentane, isooctane, toluene, chloroform, ether and ethanol in a rapid and in a slow manner. Rapid crystallizations, yielding powder like material, were carried out at room tem perature, by passing a stream of nitrogen gas over a saturated solution. Slow crystallizations, giving larger crystals, were carried out at controlled constant temperature (298 K, $295 \mathrm{~K}, 283 \mathrm{~K}, 279 \mathrm{~K}$, and $259 \mathrm{~K}$ ) on saturated solutions, by evaporating the solvent in a gradual manner.

\section{X-Ray powder diffraction analysis}

Diffraction patterns were recorded in a horizontally mounted, $120^{\circ}$ and $25 \mathrm{~cm}$ of radius curved, position sensitive detector INEL CPS 120 in transmission geometry. The detector was used in its 4096 channel resolution mode. Samples were placed in $0.5 \mathrm{~mm}$ diameter glass Lindemann capillaries. $\mathrm{Cu} \mathrm{K}(\alpha 1)$ radiation was selected by means of a Ge (llll 111$)$ primary flat monochromator. A parabolic multiplayer mirror, 'OSMIC Gutman optics \# 13B 413', was placed between the tube and the monochromator. $\mathrm{Na}_{2} \mathrm{Ca}_{3} \mathrm{Al}_{2} \mathrm{~F}_{14}$ (NAC) was used as an external standard to calibrate the detector and convert the channels to $2 \theta$ values. The data were linearized to a constant step size of $0.029^{\circ}$ in $2 \theta$ by means of a cubic spline function. Calibration and linearization were performed with the Peakoc INEL software. ${ }^{31}$ The acquisition times for the room tem perature analysis were at least $13 \mathrm{~h}$. The temperature depen dent analyses were performed in the FURCAP device from INEL that enables heating of capillary samples from room temperature to $523 \mathrm{~K}$. Data acquisition was carried out at several temperatures from room temperature to melting point, and such that, after 15 minutes of stabilization, diffraction patterns were recorded during 90 minutes.

Diffraction patterns of the $\mathrm{C}$ form were indexed using the $\mathrm{X}$ Cell algorithm. ${ }^{32}$ The final parameters of the $\mathrm{C}$ form were determined after Rietveld refinement of the structures solved by our group with MATERIALS STUDIO, ${ }^{33,34}$ a software package for crystal structure determination from $\mathrm{X}$ ray pow der diffraction data. Diffraction patterns of the B and $\mathrm{E}$ forms were indexed using DICVOL ${ }^{35}$ software and refined with the FULLPROF $^{36}$ program using the pattern matching option.

\section{Infrared spectroscopy}

The infrared spectra were obtained from a Bomem DA3 FTIR spectrometer equipped with a MCT (mercury cadmium telluride) detector. All samples were finely powdered and measured at room temperature using a diffuse reflection accessory (DRIFT) under a nitrogen gas atmosphere. The scanned range was $4004000 \mathrm{~cm}^{-1}$, with a resolution of $4 \mathrm{~cm}^{-1}$. Each spectrum was recorded by averaging 100 scans.

\section{Differential scanning calorimeter (DSC)}

At atmospheric pressure, calorimetric measurements were made with a Perkin Elmer DSC 7 calorimeter. In sealed aluminium pans, the samples were heated, cooled and heated again, at a constant rate of $2 \mathrm{~K} \mathrm{~min}^{-1}$. Analyses were performed from $273 \mathrm{~K}$ to reach the liquid phase. A minimum of three analyses per sample was done. The amount of sample used for each measurement ranged between 4.7 and $4.9 \mathrm{mg}$. The instrument was calibrated using indium and $n$ decane as external standards to determine temperature and enthalpy. The systematic uncertainties of temperatures and heat flow calibration coefficients for the DSC were evaluated as $\pm 0.2 \mathrm{~K}$ and $\pm 2 \%$, respectively. The random part of the uncertainties associated with each measurement was calculated according to the Student's method with a threshold of $95 \%$ reliability.

DTA measurements at different pressures were carried out with the equipment described by Pingel et al. ${ }^{37}$ The samples were enclosed in small containers moulded from indium. Compressed silicon oil was used as a pressure medium and the temperature increase was adjusted to $2 \mathrm{~K} \mathrm{~min}^{-1}$. The temperature values were measured with thermocouples during the heating run.

\section{Scanning electron microscopy (SEM)}

Images were taken to study the morphology of the different forms of the $n$ carboxylic acids. A Stereoscan 360 SEM (Cam bridge Instruments Ltd), working at an accelerating voltage of $2 \mathrm{kV}$ and a beam current of 60 to $70 \mathrm{pA}$, was used to observe the crystal shape of the $E_{m / o}$ forms. All samples were studied mounted on a biadhesive carbon sheet, and sputtered with gold. Due to the thermolability of the samples the sputtering was done at a very slow rate. A field emission SEM (model $\mathrm{S} 4100$ ), working at an accelerating voltage of $5 \mathrm{kV}$ and a beam current of $8 \mu \mathrm{A}$, was used to study the crystal shape of the $\mathrm{B}_{\mathrm{m} / \mathrm{o}}, \mathrm{C}, \mathrm{A}_{2}$ and $\mathrm{A}_{\text {super }}$ forms. In this case the samples were sputtered with carbon. 

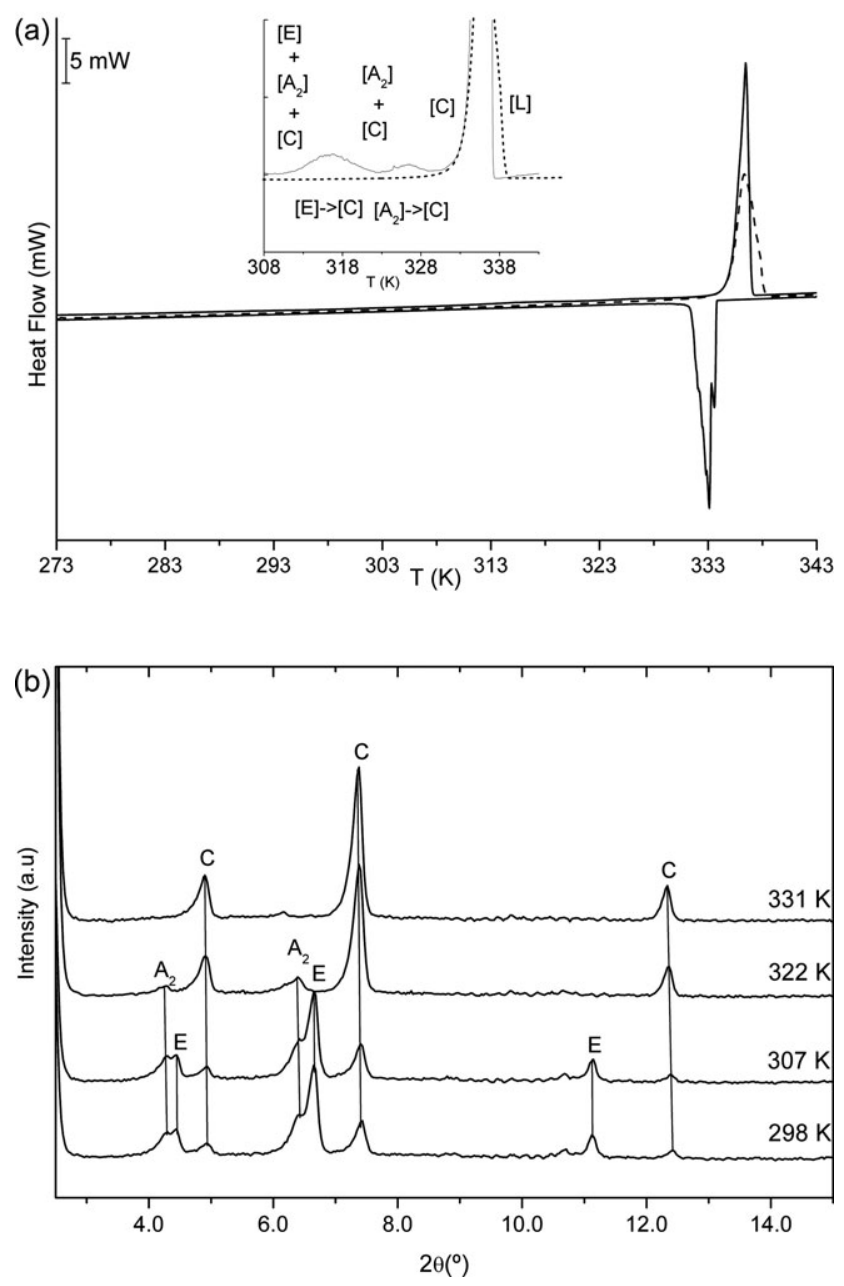

Fig. 4 (a) DSC analysis at $2 \mathrm{~K} \mathrm{~min}{ }^{1}$ and (b) powder $\mathrm{X}$ ray diffrac tion patterns at increasing temperatures of a mixture of $\mathrm{E}, \mathrm{A}_{2}$ and $\mathrm{C}$ forms in a sample of $\mathrm{C}_{16} \mathrm{H}_{31} \mathrm{O}_{2} \mathrm{H}$. The inset in part (a) shows the first order solid solid transitions from each individual form to the $\mathrm{C}$ form during the first heating process (solid line). Solid solid transforma tions are not observed during the second heating process (dotted line).

\section{Results and discussion}

\section{Occurrence of the different forms}

Seven crystal forms called $\mathrm{A}_{2}, \mathrm{~A}_{\text {super }}, \mathrm{B}_{\mathrm{o}}, \mathrm{B}_{\mathrm{m}}, \mathrm{E}_{\mathrm{o}}, \mathrm{E}_{\mathrm{m}}$ and $\mathrm{C}$, were observed in the present study for even $n$ carboxylic acids from ten to twenty carbon atoms. The different forms crystal lize from solvents individually or, usually, as a mixture and do not convert to other forms at room temperature. On heating, all the forms transform irreversibly to the $\mathrm{C}$ form, before melting by means of a first order solid solid transition, and recrystallize into the $\mathrm{C}$ form on cooling. On the second heating, only the melting of the $\mathrm{C}$ form is observed (Fig. 4). Thus, once the $\mathrm{C}$ form is obtained it remains stable.

The influence of the polarity of the solvent and the rate of crystallization on the polymorphism was studied systemati cally for $\mathrm{C}_{14} \mathrm{H}_{27} \mathrm{O}_{2} \mathrm{H}$ and $\mathrm{C}_{16} \mathrm{H}_{31} \mathrm{O}_{2} \mathrm{H}$, and to a lesser extent for the remaining acids. The results obtained are summarized
Table 2 Crystal forms observed from room temperature crystalliza tions. Predominant forms are in bold and trace forms are between parentheses

\begin{tabular}{|c|c|c|c|c|c|c|}
\hline \multirow[b]{2}{*}{ Acid } & \multicolumn{3}{|c|}{ Rapid crystallization } & \multicolumn{3}{|c|}{ Slow crystallization } \\
\hline & $\mathrm{WPS}^{a}$ & IPS $^{b}$ & $\operatorname{SPS}^{c}$ & $\mathrm{WPS}^{a}$ & IPS $^{b}$ & SPS $^{c}$ \\
\hline $\mathrm{C}_{14} \mathrm{H}_{27} \mathrm{O}_{2} \mathrm{H}$ & $\begin{array}{l}\mathbf{A}_{2} \\
\mathbf{A}_{\text {super }} \\
\mathrm{C}\end{array}$ & $\begin{array}{l}\mathbf{C} \\
\mathrm{A}_{2} \\
\mathrm{~A}_{\text {super }}\end{array}$ & $\begin{array}{l}\mathbf{C} \\
\left(\mathrm{A}_{2}\right)\end{array}$ & $\mathbf{C}$ & $\begin{array}{l}\mathbf{A}_{\text {super }} \\
\text { (C) }\end{array}$ & $\mathbf{C}$ \\
\hline $\mathrm{C}_{16} \mathrm{H}_{31} \mathrm{O}_{2} \mathrm{H}$ & $\begin{array}{l}\mathbf{A}_{2} \\
\mathrm{C} \\
\mathrm{E}_{\mathrm{m}}\left(\mathrm{E}_{\mathrm{o}}\right)\end{array}$ & $\begin{array}{l}\mathbf{E}_{\mathbf{m}}\left(\mathrm{E}_{\mathrm{o}}\right) \\
\end{array}$ & $\mathbf{C}$ & $\begin{array}{l}\mathrm{C} \\
\mathrm{A}_{2}\end{array}$ & $\begin{array}{l}\mathbf{C} \\
\mathrm{A}_{\text {super }}\end{array}$ & $\mathbf{B}_{\mathbf{m}}$ \\
\hline $\mathrm{C}_{18} \mathrm{H}_{35} \mathrm{O}_{2} \mathrm{H}$ & $\begin{array}{l}\mathbf{E}_{\mathbf{m}} \\
\mathrm{C}\end{array}$ & $\mathbf{E}_{\mathbf{m}}\left(\mathrm{E}_{\mathrm{o}}\right)$ & & $\begin{array}{l}\mathbf{B}_{\mathbf{o}} \\
\mathrm{B}_{\mathrm{m}} \\
\mathbf{A}_{2}\end{array}$ & $\begin{array}{l}\mathbf{B}_{\mathbf{o}} \\
\mathrm{B}_{\mathrm{m}} \\
\mathbf{A}_{\mathbf{2}} \\
\mathbf{E}_{\mathbf{m}} \\
\mathbf{C}\end{array}$ & \\
\hline $\mathrm{C}_{20} \mathrm{H}_{39} \mathrm{O}_{2} \mathrm{H}$ & $\mathbf{E}_{\mathbf{m}}$ & $\mathbf{E}_{\mathbf{m}}\left(\mathrm{E}_{\mathrm{o}}\right)$ & & $\mathbf{B}_{\mathbf{o}}$ & $\begin{array}{l}\mathbf{B}_{\mathbf{o}} \\
\mathbf{E}_{\mathbf{m}}\end{array}$ & \\
\hline
\end{tabular}

${ }^{a}$ WPS refers to weak polar solvents (pentane and isooctane). ${ }^{b}$ IPS refers to intermediate polar solvents (toluene, chloroform and diethyl ether). ${ }^{c}$ SPS refers to strong polar solvents (ethanol).

in Table 2 and do not show any evidence of a systematic behaviour such as to control the "polymorphic purity" of the precipitate. The different crystal forms often crystallize to gether, yielding a mixture of polymorphs for all the acids studied. Nevertheless, some general tendencies regarding the occurrence of the different forms are observed.

Acids $\mathrm{C}_{10} \mathrm{H}_{19} \mathrm{O}_{2} \mathrm{H}$ and $\mathrm{C}_{12} \mathrm{H}_{23} \mathrm{O}_{2} \mathrm{H}$ crystallize only as the $\mathrm{C}$ form in our study. However, other authors described the $\mathrm{A}_{1}$ and the $\mathrm{A}_{\text {super }}$ forms for $\mathrm{C}_{12} \mathrm{H}_{23} \mathrm{O}_{2} \mathrm{H} .{ }^{13,14}$ In addition, the occurrence of $\mathrm{C}_{12} \mathrm{H}_{23} \mathrm{O}_{2} \mathrm{H}$ in the $\mathrm{B}$ form was mentioned by Clark. ${ }^{38}$

Acid $\mathrm{C}_{14} \mathrm{H}_{27} \mathrm{O}_{2} \mathrm{H}$ crystallizes mainly as the triclinic $\mathrm{A}_{2}$ and $\mathrm{A}_{\text {super }}$ forms for the majority of the rapid crystallization experiments, whereas the $\mathrm{C}$ form predominates for the slow crystallization experiments. Pure $\mathrm{A}_{2}$ form is obtained from slow crystallization in pentane at $283 \mathrm{~K}$. Pure $A_{\text {super }}$ form is obtained from slow crystallization in diethyl ether at $298 \mathrm{~K}$ and pure $\mathrm{C}$ form is obtained from slow crystallization in isooctane at $295 \mathrm{~K}$.

Acid $\mathrm{C}_{16} \mathrm{H}_{31} \mathrm{O}_{2} \mathrm{H}$ crystallizes as $\mathrm{A}_{2}, \mathrm{C}$ and $\mathrm{E}_{\mathrm{m}}$, with traces of $\mathrm{E}_{\mathrm{o}}$ form (denoted $\mathrm{E}_{\mathrm{m}}\left(\mathrm{E}_{\mathrm{o}}\right)$ ) from the rapid crystallization experiments. From slow crystallization experiments $A_{2}, A_{\text {super }}$, $\mathrm{C}$ and $\mathrm{B}_{\mathrm{m}}$ forms are obtained. Independently of the crystal lization rate, the $\mathrm{A}_{2}$ form is obtained from weakly polar solvents (pentane and isooctane). This form crystallizes as needle like crystals in the walls of the crystallization vessel which are selected for their individual characterization. Pure $\mathrm{A}_{\text {super }}$ form is obtained from very slow crystallizations in toluene at $295 \mathrm{~K}$. The $\mathrm{B}_{\mathrm{m}}$ form is obtained from slow crystal lization in ethanol at room temperature and in chloroform at $259 \mathrm{~K}$. Pure C form is obtained in the vast majority of slow crystallization experiments at $298 \mathrm{~K}$. Pure $\mathrm{E}_{\mathrm{m}}$ form is never ob tained as traces of $\mathrm{E}_{\mathrm{o}}$ form are always present in the samples.

Acid $\mathrm{C}_{18} \mathrm{H}_{35} \mathrm{O}_{2} \mathrm{H}$ crystallizes as the $\mathrm{E}_{\mathrm{m}}$, with traces of $\mathrm{E}_{\mathrm{o}}$, and $\mathrm{C}$ forms from rapid crystallization experiments, the $\mathrm{E}_{\mathrm{m}}$ form being the predominant one. Forms $\mathrm{A}_{2}, \mathrm{~B}_{\mathrm{o}}, \mathrm{B}_{\mathrm{m}}, \mathrm{E}_{\mathrm{m}}$ and $\mathrm{C}$ are obtained from slow crystallizations, the $\mathrm{B}_{\mathrm{o}}$ form being the predominant one. As for $\mathrm{C}_{16} \mathrm{H}_{31} \mathrm{O}_{2} \mathrm{H}$, crystals of the $\mathrm{A}_{2}$ form 
are selected for characterization from slow crystallizations in isooctane at $298 \mathrm{~K}$. Pure $\mathrm{B}_{\mathrm{m}}$ form was obtained from slow crystallization in toluene at $279 \mathrm{~K}$. From toluene at $298 \mathrm{~K}$, the $\mathrm{B}_{\mathrm{o}}$ form with traces of $\mathrm{B}_{\mathrm{m}}$ form was obtained.

Acid $\mathrm{C}_{20} \mathrm{H}_{39} \mathrm{O}_{2} \mathrm{H}$ crystallizes into the $\mathrm{E}_{\mathrm{m}}$ and $\mathrm{E}_{\mathrm{o}}$ forms from rapid crystallization experiments, the $E_{m}$ form being the predominant one. From slow crystallization experiments the $\mathrm{B}_{\mathrm{o}}$ and $\mathrm{E}_{\mathrm{m}}$ forms were obtained the $\mathrm{B}_{\mathrm{o}}$ being the predominant one. Pure $B_{o}$ is obtained from slow crystallization experiments in toluene at $298 \mathrm{~K}$. In addition, the $\mathrm{B}_{\mathrm{m}}$ form, accompanied by traces of the $\mathrm{B}_{\mathrm{o}}$ form, is obtained from slow crystallization experiments in toluene at $279 \mathrm{~K}$.

\section{Thermal behaviour and stability}

The solid solid transitions and the solid liquid phenomena were analysed by means of DSC directly after the preparation of the sample (Table 3 and Table 4).

The literature data concerning the solid solid transition are rather confused and incomplete; the polymorphs are not clearly specified and the data disagree among the different authors and with the results of the present investigation. The differences can be attributed to many factors: the purity of the samples, the nature of the solid phases involved and the method used to determine the transition temperatures.

Measurements of the solubility and the melting points of the $\mathrm{B}, \mathrm{C}$ and $\mathrm{A}$ forms (without making any distinction between $\mathrm{B}_{\mathrm{o}}$ and $\mathrm{B}_{\mathrm{m}}$ and between the different $\mathrm{A}$ forms) were undertaken by Sato and co workers ${ }^{42}$ in order to determine their stability relationships. They measured the solubility of the $\mathrm{B}$ and $\mathrm{C}$ forms of $\mathrm{C}_{18} \mathrm{H}_{35} \mathrm{O}_{2} \mathrm{H}$ in $n$ decane, butanone and methanol at temperatures ranging from 271 to $311 \mathrm{~K}$ and found that $\mathrm{B}$ has the lowest solubility (is the most stable form) below $302 \mathrm{~K}, \mathrm{C}$ having the lowest solubility above this temperature. Measure ments carried out with the A form showed that it was metastable (higher solubilities) over the whole range of tem peratures studied. Further experiments carried out by Sato point to the same conclusion: the $\mathrm{B}$ and $\mathrm{C}$ forms co exist at certain temperatures $\left(297,305,313\right.$ and $319 \mathrm{~K}$ for $\mathrm{C}_{16} \mathrm{H}_{31} \mathrm{O}_{2} \mathrm{H}$, $\mathrm{C}_{18} \mathrm{H}_{35} \mathrm{O}_{2} \mathrm{H}, \mathrm{C}_{20} \mathrm{H}_{39} \mathrm{O}_{2} \mathrm{H}$ and $\mathrm{C}_{22} \mathrm{H}_{43} \mathrm{O}_{2} \mathrm{H}$, respectively); $\mathrm{B}$ is stable below and $\mathrm{C}$ is stable above that temperature, $\mathrm{A}$ being metastable throughout. ${ }^{9,43-45}$

The differences regarding the temperature of the $\mathrm{B} \rightarrow \mathrm{C}$ transition between Sato's data (solubility measurements) and the present work (DSC measurements, Table 3) could be attributed to kinetic effects since the solid state transitions between the polymorphic modifications are kinetically hin dered due to certain steric effects involving rearrangements in the molecular conformation and the angle of tilt of the molecules within the cell. ${ }^{9}$

To confirm the stability regions determined by solubility experiments, DTA measurements at different pressures in the range 5001500 bar were performed in order to determine the temperature pressure equilibrium diagram. ${ }^{46}$ Samples of $\mathrm{C}_{18} \mathrm{H}_{35} \mathrm{O}_{2} \mathrm{H}$ in $\mathrm{C}, \mathrm{B}_{\mathrm{o}}$ and $\mathrm{E}_{\mathrm{m}}$ forms were used in the experi ments, the $B_{o}$ and $E_{m}$ forms containing traces of $B_{m}$ and $E_{o}$ forms, respectively. The obtained results do not give any further information since the $\mathrm{B}_{\mathrm{o}} \rightarrow \mathrm{C}$ and the $\mathrm{E}_{\mathrm{m}} \rightarrow \mathrm{C}$ transitions cannot be detected with the equipment used. The
Table 3 Solid solid transition measured temperatures and enthalpies Solid solid transition ${ }^{a}$

\begin{tabular}{|c|c|c|c|c|}
\hline Acid & Phase & $T / \mathrm{K}$ & $\Delta H / \mathrm{kJ} \mathrm{mol}^{1}$ & Ref. \\
\hline $\mathrm{C}_{12} \mathrm{H}_{23} \mathrm{O}_{2} \mathrm{H}$ & $\mathrm{A}_{\text {super }}$ & 308.1 & & 8 \\
\hline $\mathrm{C}_{12} \mathrm{H}_{23} \mathrm{O}_{2} \mathrm{H}$ & B & 283.1 & & 38 \\
\hline $\mathrm{C}_{14} \mathrm{H}_{27} \mathrm{O}_{2} \mathrm{H}$ & $\mathrm{A}_{2}$ & $315.0 \pm 1.5$ & $1.8 \pm 0.4$ & This work \\
\hline $\mathrm{C}_{14} \mathrm{H}_{27} \mathrm{O}_{2} \mathrm{H}$ & $\mathrm{A}_{\text {super }}$ & $325.3 \pm 0.4$ & $6.4 \pm 0.7$ & This work \\
\hline $\mathrm{C}_{14} \mathrm{H}_{27} \mathrm{O}_{2} \mathrm{H}$ & A & 317.1 & & 39 \\
\hline $\mathrm{C}_{14} \mathrm{H}_{27} \mathrm{O}_{2} \mathrm{H}$ & B & 298.1 & & 38 \\
\hline $\mathrm{C}_{16} \mathrm{H}_{31} \mathrm{O}_{2} \mathrm{H}$ & $\mathrm{A}_{2}$ & $324.7 \pm 0.6$ & $2.6 \pm 0.7$ & This work \\
\hline $\mathrm{C}_{16} \mathrm{H}_{31} \mathrm{O}_{2} \mathrm{H}$ & $\mathrm{A}_{\text {super }}$ & $331.0 \pm 0.5$ & $7.6 \pm 0.5$ & This work \\
\hline $\mathrm{C}_{16} \mathrm{H}_{31} \mathrm{O}_{2} \mathrm{H}$ & A & 332.1 & & 39 \\
\hline $\mathrm{C}_{16} \mathrm{H}_{31} \mathrm{O}_{2} \mathrm{H}$ & $\mathrm{E}_{\mathrm{m}}$ & $316.7 \pm 0.7$ & $3.1 \pm 0.2^{c}$ & This work \\
\hline $\mathrm{C}_{16} \mathrm{H}_{31} \mathrm{O}_{2} \mathrm{H}$ & $\mathrm{B}_{\mathrm{m}}$ & $317.5 \pm 0.6$ & $4.9 \pm 0.4$ & This work \\
\hline $\mathrm{C}_{16} \mathrm{H}_{31} \mathrm{O}_{2} \mathrm{H}$ & B & 313.1 & & 38 \\
\hline $\mathrm{C}_{18} \mathrm{H}_{35} \mathrm{O}_{2} \mathrm{H}$ & $\mathrm{A}_{2}$ & $331.6 \pm 0.2$ & $2.8 \pm 0.3^{b}$ & This work \\
\hline $\mathrm{C}_{18} \mathrm{H}_{35} \mathrm{O}_{2} \mathrm{H}$ & A & 327.1 & & 39 \\
\hline $\mathrm{C}_{18} \mathrm{H}_{35} \mathrm{O}_{2} \mathrm{H}$ & A & 337.1 & & 9 \\
\hline $\mathrm{C}_{18} \mathrm{H}_{35} \mathrm{O}_{2} \mathrm{H}$ & $\mathrm{E}_{\mathrm{m}}$ & $327.4 \pm 0.6$ & $4.3 \pm 0.3^{c}$ & This work \\
\hline $\mathrm{C}_{18} \mathrm{H}_{35} \mathrm{O}_{2} \mathrm{H}$ & $\mathrm{E}$ & 316.6 & & 9 \\
\hline $\mathrm{C}_{18} \mathrm{H}_{35} \mathrm{O}_{2} \mathrm{H}$ & $\mathrm{B}_{\mathrm{m}}$ & $324.4 \pm 0.7$ & $5.4 \pm 0.3$ & This work \\
\hline $\mathrm{C}_{18} \mathrm{H}_{35} \mathrm{O}_{2} \mathrm{H}$ & $\mathrm{B}_{\mathrm{o}}$ & $325.9 \pm 0.5$ & $5.7 \pm 0.3^{c}$ & This work \\
\hline $\mathrm{C}_{18} \mathrm{H}_{35} \mathrm{O}_{2} \mathrm{H}$ & B & 324.1 & 5.1 & 9 \\
\hline $\mathrm{C}_{18} \mathrm{H}_{35} \mathrm{O}_{2} \mathrm{H}$ & B & 328.1 & & 38 \\
\hline $\mathrm{C}_{18} \mathrm{H}_{35} \mathrm{O}_{2} \mathrm{H}$ & B & 319.1 & & 39 \\
\hline $\mathrm{C}_{20} \mathrm{H}_{39} \mathrm{O}_{2} \mathrm{H}$ & $\mathrm{E}_{\mathrm{m}}$ & $332.8 \pm 0.4$ & $4.1 \pm 0.3$ & This work \\
\hline $\mathrm{C}_{20} \mathrm{H}_{39} \mathrm{O}_{2} \mathrm{H}$ & $\mathrm{B}_{\mathrm{o}}$ & $333.3 \pm 0.6$ & $6.1 \pm 0.2$ & This work \\
\hline $\mathrm{C}_{20} \mathrm{H}_{39} \mathrm{O}_{2} \mathrm{H}$ & $\mathrm{B}_{\mathrm{m}}$ & $332.6 \pm 0.4$ & $5.9 \pm 0.2^{c}$ & This work \\
\hline $\mathrm{C}_{20} \mathrm{H}_{39} \mathrm{O}_{2} \mathrm{H}$ & B & 325.1 & & 39 \\
\hline
\end{tabular}

${ }^{a}$ The solid solid transition involves the transformation from the room temperature form to the $\mathrm{C}$ form. ${ }^{b}$ Enthalpy obtained from one analysis. The error bar is estimated by comparison with the rest of the results. ${ }^{c}$ The enthalpy is underestimated since traces of another form $\left(\mathrm{E}_{\mathrm{o} / \mathrm{m}}\right.$ or $\left.\mathrm{B}_{\mathrm{o} / \mathrm{m}}\right)$ are present in the samples analyzed.

Table 4 Melting temperatures and enthalpies measured on heating at normal pressure. The solid liquid transition always involves the transformation from the $\mathrm{C}$ form to liquid phase

\begin{tabular}{llll}
\hline Acid & $T / \mathrm{K}$ & $\Delta H / \mathrm{kJ}$ mol & Ref. \\
\hline $\mathrm{C}_{10} \mathrm{H}_{19} \mathrm{O}_{2} \mathrm{H}$ & $303.8 \pm 0.6$ & $28.3 \pm 0.7$ & This work \\
$\mathrm{C}_{10} \mathrm{H}_{19} \mathrm{O}_{2} \mathrm{H}$ & 305 & & 25 \\
$\mathrm{C}_{10} \mathrm{H}_{19} \mathrm{O}_{2} \mathrm{H}$ & $304.5 \pm 0.1$ & $28.0 \pm 0.1$ & 40 \\
$\mathrm{C}_{10} \mathrm{H}_{19} \mathrm{O}_{2} \mathrm{H}$ & $304.7 \pm 0.1$ & $29.4 \pm 1.2$ & 41 \\
$\mathrm{C}_{12} \mathrm{H}_{23} \mathrm{O}_{2} \mathrm{H}$ & $316.2 \pm 0.4$ & $36.1 \pm 0.8$ & This work \\
$\mathrm{C}_{12} \mathrm{H}_{23} \mathrm{O}_{2} \mathrm{H}$ & 318 & & 25 \\
$\mathrm{C}_{12} \mathrm{H}_{23} \mathrm{O}_{2} \mathrm{H}$ & 317.1 & & 39 \\
$\mathrm{C}_{12} \mathrm{H}_{23} \mathrm{O}_{2} \mathrm{H}$ & $316.9 \pm 0.1$ & $36.3 \pm 0.1$ & 40 \\
$\mathrm{C}_{12} \mathrm{H}_{23} \mathrm{O}_{2} \mathrm{H}$ & $317.2 \pm 0.1$ & $36.7 \pm 1.5$ & 41 \\
$\mathrm{C}_{14} \mathrm{H}_{27} \mathrm{O}_{2} \mathrm{H}$ & $326.5 \pm 0.5$ & $45.0 \pm 1.3$ & This work \\
$\mathrm{C}_{14} \mathrm{H}_{27} \mathrm{O}_{2} \mathrm{H}$ & 328 & & 25 \\
$\mathrm{C}_{14} \mathrm{H}_{27} \mathrm{O}_{2} \mathrm{H}$ & 327.3 & & 39 \\
$\mathrm{C}_{14} \mathrm{H}_{27} \mathrm{O}_{2} \mathrm{H}$ & $327.3 \pm 0.1$ & $45.1 \pm 0.1$ & 40 \\
$\mathrm{C}_{14} \mathrm{H}_{27} \mathrm{O}_{2} \mathrm{H}$ & $327.4 \pm 0.1$ & $44.7 \pm 1.8$ & 41 \\
$\mathrm{C}_{16} \mathrm{H}_{31} \mathrm{O}_{2} \mathrm{H}$ & $334.7 \pm 0.5$ & $53.0 \pm 1.0$ & This work \\
$\mathrm{C}_{16} \mathrm{H}_{31} \mathrm{O}_{2} \mathrm{H}$ & 336.0 & & 39 \\
$\mathrm{C}_{16} \mathrm{H}_{31} \mathrm{O}_{2} \mathrm{H}$ & $335.6 \pm 0.1$ & $53.7 \pm 0.1$ & 40 \\
$\mathrm{C}_{16} \mathrm{H}_{31} \mathrm{O}_{2} \mathrm{H}$ & $335.8 \pm 0.1$ & $53.4 \pm 2.1$ & 41 \\
$\mathrm{C}_{18} \mathrm{H}_{35} \mathrm{O}_{2} \mathrm{H}$ & $342.4 \pm 0.3$ & $63.2 \pm 1.4$ & This work \\
$\mathrm{C}_{18} \mathrm{H}_{35} \mathrm{O}_{2} \mathrm{H}$ & 342.8 & & 39 \\
$\mathrm{C}_{18} \mathrm{H}_{35} \mathrm{O}_{2} \mathrm{H}$ & $342.5 \pm 0.1$ & $61.2 \pm 0.2$ & 40 \\
$\mathrm{C}_{18} \mathrm{H}_{35} \mathrm{O}_{2} \mathrm{H}$ & $342.6 \pm 0.1$ & $63.0 \pm 2.5$ & 41 \\
$\mathrm{C}_{20} \mathrm{H}_{39} \mathrm{O}_{2} \mathrm{H}$ & $347.6 \pm 0.3$ & $71.6 \pm 1.6$ & This work \\
$\mathrm{C}_{20} \mathrm{H}_{39} \mathrm{O}_{2} \mathrm{H}$ & 348.2 & & 39 \\
$\mathrm{C}_{20} \mathrm{H}_{39} \mathrm{O}_{2} \mathrm{H}$ & $348.2 \pm 0.1$ & $69.2 \pm 0.4$ & 40 \\
$\mathrm{C}_{20} \mathrm{H}_{39} \mathrm{O}_{2} \mathrm{H}$ & $348.4 \pm 0.1$ & $72.0 \pm 2.8$ & 41 \\
\hline
\end{tabular}


Table 5 Calculated lattice energies ( $E_{\text {lattice }}$ ) of the $\mathrm{C}, \mathrm{E}_{\mathrm{o}}, \mathrm{E}_{\mathrm{m}}$ and $\mathrm{B}_{\mathrm{o}}$ forms of $\mathrm{C}_{18} \mathrm{H}_{35} \mathrm{O}_{2} \mathrm{H}$ using the COMPASS force field ${ }^{47}$

\begin{tabular}{ll}
\hline Crystal form & $\mid E_{\text {latticel }} / \mathrm{kJ} \mathrm{mol}^{1}$ \\
\hline $\mathrm{C}$ & 189 \\
$\mathrm{E}_{\mathrm{o}}$ & 194 \\
$\mathrm{E}_{\mathrm{m}}$ & 194 \\
$\mathrm{~B}_{\mathrm{o}}$ & 195 \\
\hline
\end{tabular}

energy of these transitions is not sufficiently large and the peaks not sufficiently sharp to give a reliable DTA signal. Only the melting phenomenon, which involves the transition from the $\mathrm{C}$ phase to liquid, is sufficiently energetic and sharp as to give a reliable signal.

To complement these results, lattice energy calculations were undertaken with the single crystal structures of the $\mathrm{B}_{\mathrm{o}}{ }^{22} \mathrm{E}_{\mathrm{m}},{ }^{23}$ and $\mathrm{E}_{\mathrm{o}}{ }^{24}$ forms of $\mathrm{C}_{18} \mathrm{H}_{35} \mathrm{O}_{2} \mathrm{H}$ available in the literature, and the structure of the $\mathrm{C}$ form solved from powder data in our group. Using the COMPASS ${ }^{47}$ force field, all the structures were fully optimized and the lattice energy calcu lated in order to predict the relative stability of the different polymorphs. The $\mathrm{B}_{\mathrm{m}}$ form was discarded since the reported structure is incomplete; coordinates of the hydroxylic hydro gen are omitted. The enthalpy of sublimation, $\Delta H_{\text {sub }}$, of a solid is the experimental thermodynamic quantity describing the stability of the crystal structure. This enthalpy can be defined by eqn (1), where the lattice energy, $E_{\text {lattice, then }}$ constitutes an approximation to $\Delta H_{\text {sub }}$ and consequently to the stability of a crystal. ${ }^{48}$ According to the calculated lattice energies displayed in Table 5, the $\mathrm{B}_{\mathrm{o}}$ and the $\mathrm{E}_{\mathrm{o} / \mathrm{m}}$ forms of $\mathrm{C}_{18} \mathrm{H}_{35} \mathrm{O}_{2} \mathrm{H}$ are more stable than the $\mathrm{C}$ form by 6 and $5 \mathrm{~kJ}$ $\mathrm{mol}^{-1}$, respectively, at $0 \mathrm{~K}$, which agrees with the conclusions reported by Sato from solubility experiments.

$$
\Delta H_{\text {sub }} \quad E_{\text {lattice }} \quad 2 R T
$$

\section{Structural characterization}

X Ray measurements made with the INEL CPS 120 at room temperature were used for the crystallographic characteriza
Table 7 Cell parameters for the orthorhombic polytype (Pbca, Z 8) of the B form

\begin{tabular}{lllllll}
\hline Phase & Acid & $a / \AA$ & $b / \AA$ & $c / \AA$ & $V / \AA^{3}$ & Ref. \\
\hline $\mathrm{B}_{\mathrm{o}}$ & $\mathrm{C}_{18} \mathrm{H}_{35} \mathrm{O}_{2} \mathrm{H}$ & $7.408(3)$ & $5.587(3)$ & $87.69(6)$ & 3629.4 & This work \\
& $\mathrm{C}_{18} \mathrm{H}_{35} \mathrm{O}_{2} \mathrm{H}$ & $7.404(1)$ & $5.591(1)$ & $87.662(9)$ & 3628.7 & 22 \\
& $\mathrm{C}_{20} \mathrm{H}_{39} \mathrm{O}_{2} \mathrm{H}$ & $7.412(1)$ & $5.592(2)$ & $96.73(2)$ & 4009.3 & This work \\
\hline
\end{tabular}

tion. Cell parameters obtained after Rietveld refinement of the $\mathrm{C}$ form for acids from $\mathrm{C}_{10} \mathrm{H}_{19} \mathrm{O}_{2} \mathrm{H}$ up to $\mathrm{C}_{20} \mathrm{H}_{39} \mathrm{O}_{2} \mathrm{H}$ (Table 6) show that the $\mathrm{C}$ form is monoclinic $\left(P 2_{1} / a, Z \quad 4\right)$. The differences compared to the previous single crystal results (ref. 25) can be explained in terms of the thermal expansion of the cell. According to these results, the cell volume of $\mathrm{C}_{10} \mathrm{H}_{19} \mathrm{O}_{2} \mathrm{H}$ changes from $1063 \AA^{3}$ at $170 \mathrm{~K}$ to $1116 \AA^{3}$ at $270 \mathrm{~K}$. Conse quently, a volume of $1129 \AA^{3}$ is expected at room temperature.

A linear evolution of $c \sin \beta$ (the thickness of a double layer of molecules) along the different members of the family is observed for the $\mathrm{C}$ form, whereas $a$ and $b$ parameters can be considered constant, concluding that the $\mathrm{C}$ form is isostruc tural for the compounds studied.

The monoclinic $\mathrm{B}_{\mathrm{m}}$ and $\mathrm{E}_{\mathrm{m}}$ polytypes of $\mathrm{C}_{16} \mathrm{H}_{31} \mathrm{O}_{2} \mathrm{H}$, $\mathrm{C}_{18} \mathrm{H}_{35} \mathrm{O}_{2} \mathrm{H}$ and $\mathrm{C}_{20} \mathrm{H}_{39} \mathrm{O}_{2} \mathrm{H}$ have space group $P 2_{1} / a$ with $Z$ 4, while the orthorhombic $\mathrm{B}_{\mathrm{o}}$ and $\mathrm{E}_{\mathrm{o}}$ polytypes have $P b c a$ space group with $Z \quad$ 8. Cell parameters are reported in Tables 7 and 8 .

According to the variation of the unit cell parameters, the $\mathrm{B}_{\mathrm{o}}$ form is isostructural for acids $\mathrm{C}_{18} \mathrm{H}_{35} \mathrm{O}_{2} \mathrm{H}$ and $\mathrm{C}_{20} \mathrm{H}_{39} \mathrm{O}_{2} \mathrm{H}$ and the $\mathrm{B}_{\mathrm{m}}$ and $\mathrm{E}_{\mathrm{m}}$ forms are isostructural for acids $\mathrm{C}_{16} \mathrm{H}_{31} \mathrm{O}_{2} \mathrm{H}, \mathrm{C}_{18} \mathrm{H}_{35} \mathrm{O}_{2} \mathrm{H}$ and $\mathrm{C}_{20} \mathrm{H}_{39} \mathrm{O}_{2} \mathrm{H}$.

The cell parameters of the triclinic forms need further crystallographic investigation in order to be determined. To date, the powder $\mathrm{X}$ ray diffraction patterns, the SEM images and the DSC analysis confirm the existence of two different types of triclinic forms: one that matches the characteristics reported by Kobayashi et al. ${ }^{30}$ for the $\mathrm{A}_{2}$ form of $\mathrm{C}_{16} \mathrm{H}_{31} \mathrm{O}_{2} \mathrm{H}$, and the other that matches the characteristics reported by von Sydow $^{29}$ and Goto and Asada ${ }^{14}$ for the $\mathrm{A}_{\text {super form of }}$ $\mathrm{C}_{12} \mathrm{H}_{23} \mathrm{O}_{2} \mathrm{H}$. For that reason we keep the notation. The

Table 6 Cell parameters of the $\mathrm{C}$ form $\left(P 2_{1} / a, Z \quad 4\right)$

\begin{tabular}{|c|c|c|c|c|c|c|c|}
\hline Acid & $a / \AA$ & $b / \AA$ & $c / \AA$ & $\beta /^{\circ}$ & $V / \AA^{3}$ & $T / \mathrm{K}$ & Ref. \\
\hline $\mathrm{C}_{10} \mathrm{H}_{19} \mathrm{O}_{2} \mathrm{H}$ & $9.834(1)$ & $4.940(1)$ & $37.47(1)$ & $141.94(1)$ & 1122.2 & 298 & This work \\
\hline $\mathrm{C}_{10} \mathrm{H}_{19} \mathrm{O}_{2} \mathrm{H}$ & $9.3977(6)$ & $4.9612(3)$ & $37.372(2)$ & $142.405(4)$ & 1063.0 & 170 & $25^{a}$ \\
\hline $\mathrm{C}_{10} \mathrm{H}_{19} \mathrm{O}_{2} \mathrm{H}$ & $9.716(7)$ & $4.973(5)$ & $37.59(3)$ & $142.10(8)$ & 1115.7 & 270 & $25^{a}$ \\
\hline $\mathrm{C}_{12} \mathrm{H}_{23} \mathrm{O}_{2} \mathrm{H}$ & $9.604(1)$ & $4.953(1)$ & $42.30(1)$ & $139.78(1)$ & 1299.5 & 298 & This work \\
\hline $\mathrm{C}_{12} \mathrm{H}_{23} \mathrm{O}_{2} \mathrm{H}$ & $9.5266(6)$ & $4.9627(3)$ & $42.379(2)$ & $139.905(2)$ & 1290.4 & 270 & $25^{a}$ \\
\hline $\mathrm{C}_{12} \mathrm{H}_{23} \mathrm{O}_{2} \mathrm{H}$ & $9.52(2)$ & $4.97(1)$ & $35.39(7)$ & $129.22(2)$ & 1297.2 & & 49 \\
\hline $\mathrm{C}_{12} \mathrm{H}_{23} \mathrm{O}_{2} \mathrm{H}$ & $9.63(2)$ & $4.966(4)$ & $35.58(8)$ & $129.6(1)$ & 1311.0 & & 50 \\
\hline $\mathrm{C}_{14} \mathrm{H}_{27} \mathrm{O}_{2} \mathrm{H}$ & $9.497(1)$ & $4.972(1)$ & $44.45(1)$ & $134.81(1)$ & 1489.0 & 298 & This work \\
\hline $\mathrm{C}_{14} \mathrm{H}_{27} \mathrm{O}_{2} \mathrm{H}$ & $9.4260(11)$ & $4.9652(5)$ & $43.972(3)$ & $134.311(4)$ & 1472.6 & 270 & $25^{a}$ \\
\hline $\mathrm{C}_{14} \mathrm{H}_{27} \mathrm{O}_{2} \mathrm{H}$ & $9.51(2)$ & $4.968(4)$ & $40.71(8)$ & $129.1(1)$ & 1492.6 & & 50 \\
\hline $\mathrm{C}_{16} \mathrm{H}_{31} \mathrm{O}_{2} \mathrm{H}$ & $9.440(1)$ & $4.975(1)$ & $45.74(1)$ & $128.65(1)$ & 1677.5 & 298 & This work \\
\hline $\mathrm{C}_{16} \mathrm{H}_{31} \mathrm{O}_{2} \mathrm{H}$ & $9.406(3)$ & $4.949(2)$ & $45.61(1)$ & $128.661(5)$ & 1658.0 & 298 & $26^{a}$ \\
\hline $\mathrm{C}_{18} \mathrm{H}_{35} \mathrm{O}_{2} \mathrm{H}$ & $9.354(1)$ & $4.960(1)$ & $50.82(1)$ & $128.38(1)$ & 1848.3 & 298 & This work \\
\hline $\mathrm{C}_{18} \mathrm{H}_{35} \mathrm{O}_{2} \mathrm{H}$ & $9.36(2)$ & $4.95(1)$ & $50.7(1)$ & $128.3(3)$ & 1843.5 & & 27 \\
\hline $\mathrm{C}_{18} \mathrm{H}_{35} \mathrm{O}_{2} \mathrm{H}$ & $9.36(2)$ & $4.956(4)$ & $50.76(8)$ & $128.2(1)$ & 1850.4 & & 50 \\
\hline $\mathrm{C}_{20} \mathrm{H}_{39} \mathrm{O}_{2} \mathrm{H}$ & $9.318(1)$ & $4.956(1)$ & $53.73(1)$ & $124.98(1)$ & 2033.2 & 298 & This work \\
\hline
\end{tabular}


Table 8 Cell parameters for the monoclinic polytype $\left(P 2_{1} / a, Z \quad 4\right)$ of the $\mathrm{B}$ and $\mathrm{E}$ forms

\begin{tabular}{llllllll}
\hline Phase & Acid & $a / \AA$ & $b / \AA$ & $c / \AA$ & $\beta /{ }^{\circ}$ & $V / \AA^{3}$ \\
\hline $\mathrm{E}_{\mathrm{m}}$ & $\mathrm{C}_{16} \mathrm{H}_{31} \mathrm{O}_{2} \mathrm{H}$ & $5.622(1)$ & $7.379(1)$ & $45.67(1)$ & $119.64(1)$ & 1646.5 \\
& $\mathrm{C}_{18} \mathrm{H}_{35} \mathrm{O}_{2} \mathrm{H}$ & $5.608(1)$ & $7.386(1)$ & $50.75(1)$ & $119.44(1)$ & 1830.7 & This work \\
& $\mathrm{C}_{18} \mathrm{H}_{35} \mathrm{O}_{2} \mathrm{H}$ & $5.603(1)$ & $7.360(1)$ & $50.789(9)$ & $119.40(2)$ & 1824.6 & 23 \\
& $\mathrm{C}_{20} \mathrm{H}_{39} \mathrm{O}_{2} \mathrm{H}$ & $5.601(1)$ & $7.384(1)$ & $54.05(1)$ & $115.34(1)$ & 2020.1 & This work \\
$\mathrm{B}_{\mathrm{m}}$ & $\mathrm{C}_{16} \mathrm{H}_{31} \mathrm{O}_{2} \mathrm{H}$ & $5.592(1)$ & $7.415(1)$ & $46.30(1)$ & $121.80(1)$ & 1631.5 & This work \\
& $\mathrm{C}_{18} \mathrm{H}_{35} \mathrm{O}_{2} \mathrm{H}$ & $5.598(1)$ & $7.397(1)$ & $49.44(2)$ & $117.24(1)$ & 1820.3 & This work \\
& $\mathrm{C}_{18} \mathrm{H}_{35} \mathrm{O}_{2} \mathrm{H}$ & $5.587(10)$ & $7.386(6)$ & $49.33(8)$ & $117.24(9)$ & 1809.9 & 21 \\
& $\mathrm{C}_{20} \mathrm{H}_{39} \mathrm{O}_{2} \mathrm{H}$ & $5.582(1)$ & $7.404(1)$ & $54.57(1)$ & $117.60(1)$ & 1998.7 & This work \\
& & & & & &
\end{tabular}

differences observed between the two triclinic forms are explained in the following sections.

\section{X-Ray powder diffraction and differential scanning calorimetry (DSC)}

To identify the different crystal forms it is convenient to divide the experimental powder diffraction pattern into two regions, the low angle region $\left(315^{\circ}\right.$ in $\left.2 \theta\right)$ and the middle angle region (19 $25^{\circ}$ in $2 \theta$ ).

In the low angle region (Fig. 5), the position of the $\left(\begin{array}{lll}0 & 0 & l\end{array}\right)$ reflections for the $P 2_{1} / a$ space group and the $P b c a$ space group allows the unambiguous identification of the $\mathrm{C}$ and the $\mathrm{A}_{2}$ forms (Fig. 5a). The presence of the $\mathrm{E}_{\mathrm{o} / \mathrm{m}}$ or the $\mathrm{B}_{\mathrm{o} / \mathrm{m}}$ forms, or even a mixture of them, can be detected according to this family of reflections but they cannot be distinguished due to their similar structures (Fig. $5 \mathrm{c}$ ). The pattern of the $\mathrm{A}_{\text {super }}$ form (Fig. 5b) shows the evenly spaced $(00 l)$ reflections, with $l$ odd absent, typical for $n$ carboxylic acids, plus further reflections that correspond to the $(0 k l)$, and the $(0 k \bar{l})$ family, the rest of the pattern being similar to that of the $\mathrm{A}_{2}$ form.
To distinguish between the $\mathrm{B}$ and the $\mathrm{E}$ forms and their orthorhombic and monoclinic polytypes, we propose guide lines 1 and 2, respectively:

(1) As shown in Fig. 6a for the $E_{o}$ and $B_{o}$ forms of $\mathrm{C}_{18} \mathrm{H}_{35} \mathrm{O}_{2} \mathrm{H}$, the $\left(\begin{array}{lll}2 & 0 & 0\end{array}\right)$ reflection (at a $2 \theta$ value around $24.1^{\circ}$ within the reported experimental conditions) is shifted to high angles for the $\mathrm{E}$ form, while it is shifted to low angles for the $\mathrm{B}$ form, independently of the polytype considered.

(2) As shown in Fig. $6 \mathrm{~b}$ for the $\mathrm{B}_{\mathrm{o}}$ and the $\mathrm{B}_{\mathrm{m}}$ polytypes of $\mathrm{C}_{18} \mathrm{H}_{35} \mathrm{O}_{2} \mathrm{H}$, the orthorhombic polytype has three reflections more than the monoclinic polytype. As observed from Fig. 6b, all reflections for the $\mathrm{B}_{\mathrm{m}}$ and $\mathrm{B}_{\mathrm{o}}$ polytypes of $\mathrm{C}_{18} \mathrm{H}_{35} \mathrm{O}_{2} \mathrm{H}$ overlap except the three reflections of the $\mathrm{B}_{\mathrm{o}}$ form that

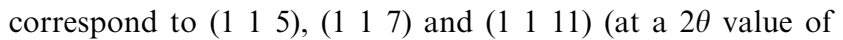
$20.52^{\circ}, 21.12^{\circ}$ and $22.82^{\circ}$, respectively, within the reported experimental conditions). An analogous behaviour is shown by the $E_{m}$ and $E_{o}$ polytypes, where all reflections overlap for both polytypes, except the reflections (lll 110$),\left(\begin{array}{lll}1 & 1 & 8\end{array}\right),\left(\begin{array}{lll}1 & 1 & 10\end{array}\right)$ and $\left(\begin{array}{lll}1 & 1 & 12\end{array}\right)$ of the orthorhombic polytype (at a $2 \theta$ value of $20.78^{\circ}, 21.46^{\circ}, 22.30^{\circ}, 23.29^{\circ}$, respectively, within the already mentioned experimental conditions).
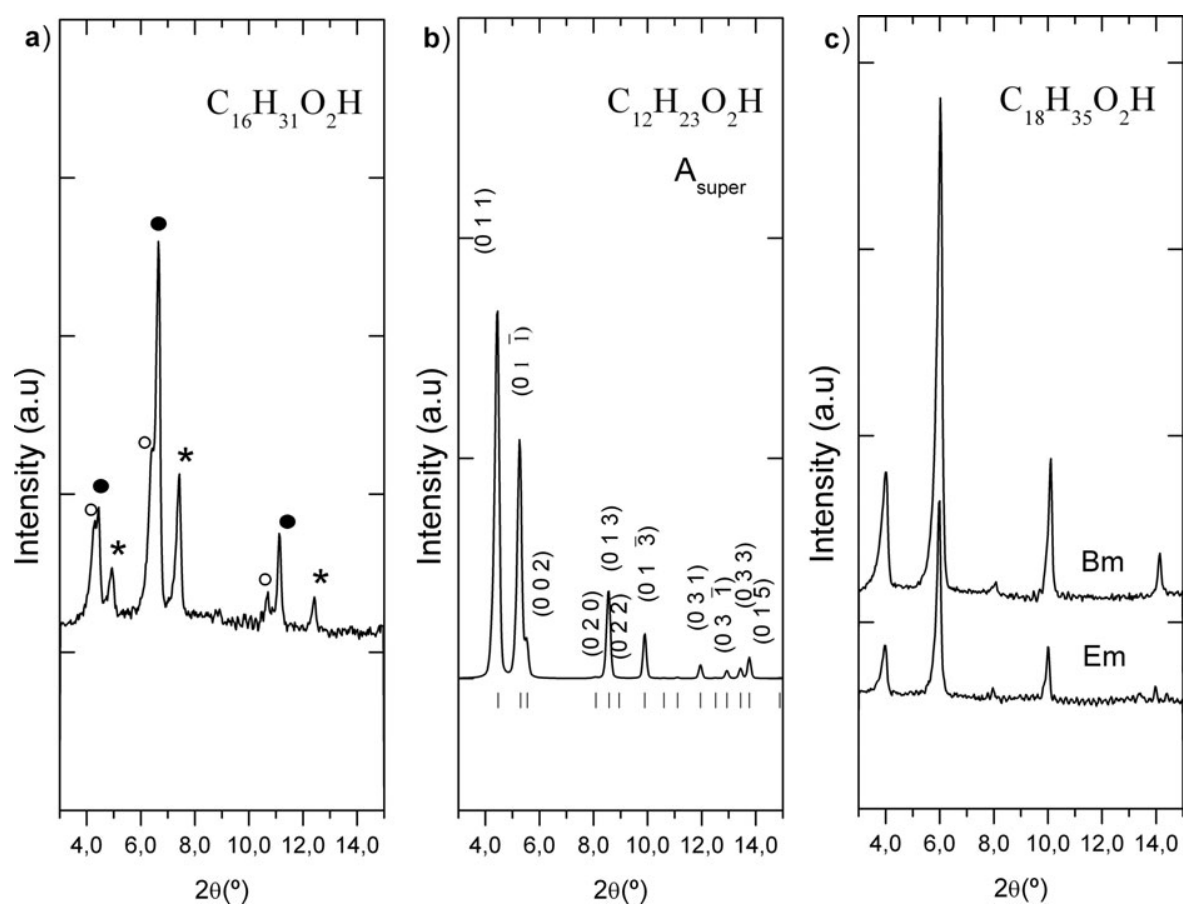

Fig. 5 Low angle $X$ ray powder diffraction patterns of (a) a mixture of $A_{2}(O), E_{m}$ $\mathrm{C}_{12} \mathrm{H}_{23} \mathrm{O}_{2} \mathrm{H}$ simulated from single crystal data ${ }^{14}$ and (c) $\mathrm{B}_{\mathrm{m}}$ and $\mathrm{E}_{\mathrm{m}}$ forms of $\mathrm{C}_{18} \mathrm{H}_{35} \mathrm{O}_{2} \mathrm{H}$.

and $\mathrm{C}(*)$ forms of $\mathrm{C}_{16} \mathrm{H}_{31} \mathrm{O}_{2} \mathrm{H}$, (b) $\mathrm{A}_{\text {super }}$ form of 

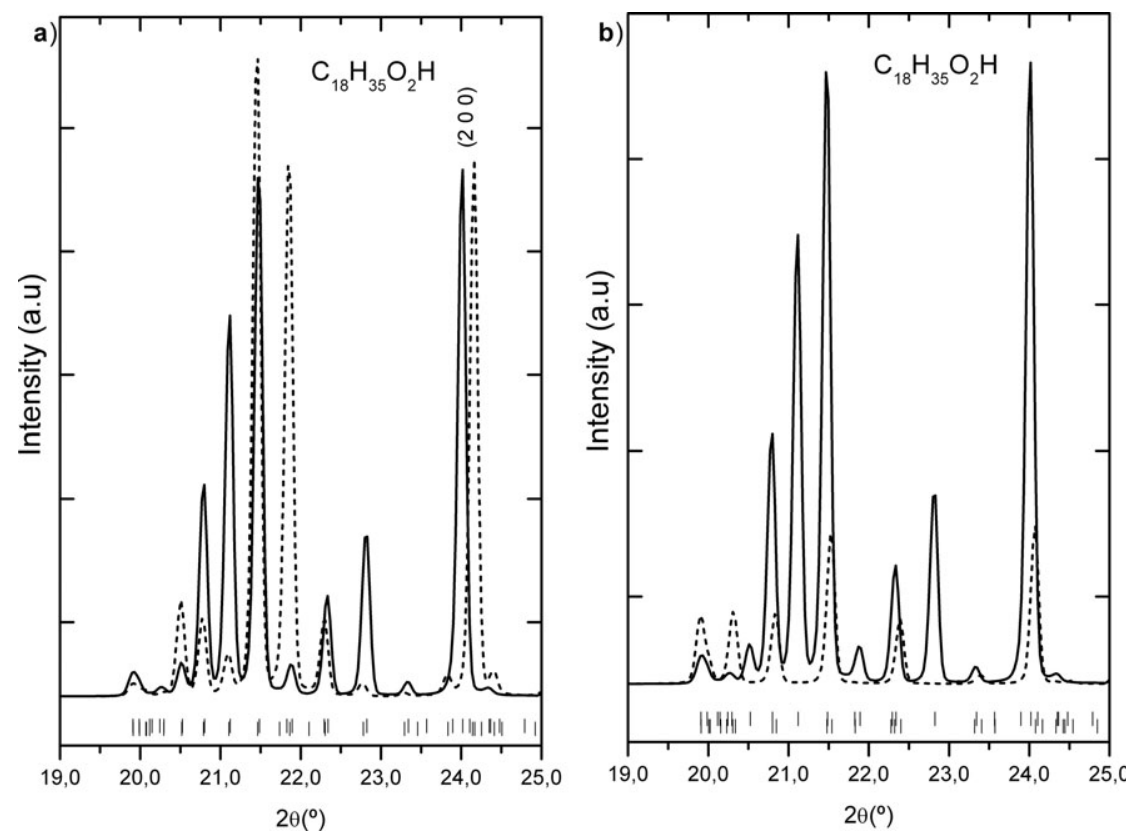

Fig. 6 Middle angle $X$ ray powder diffraction patterns and Bragg positions from single crystal data ${ }^{21,22,24}$ of (a) the form $B_{o}\left(\right.$ ) and the form $E_{o}$ ( ) of $\mathrm{C}_{18} \mathrm{H}_{35} \mathrm{O}_{2} \mathrm{H}$ and of (b) the $\mathrm{B}_{\mathrm{m}}\left(\mathrm{)}\right.$ ) and the $\mathrm{B}_{\mathrm{o}}$ ( ) forms and of $\mathrm{C}_{18} \mathrm{H}_{35} \mathrm{O}_{2} \mathrm{H}$.

When traces of one form are present in a sample, DSC is a suitable technique to confirm it since it has higher sensitivity than powder $\mathrm{X}$ ray diffraction.

Temperature, shape and enthalpy of the phase transitions are an indicator of the form present (Fig. 7). The $\mathrm{A}_{\text {super }} \rightarrow \mathrm{C}$ transformation has the highest transition point, occurs just before the melting and the curve is overlapped by the melting peak (Fig. 7a). The $\mathrm{A}_{2} \rightarrow \mathrm{C}$ transition has a broad peak and occurs at a higher temperature than $\mathrm{B}_{\mathrm{o} / \mathrm{m}} \rightarrow \mathrm{C}$ and $\mathrm{E}_{\mathrm{o} / \mathrm{m}} \rightarrow \mathrm{C}$ (Fig. 4a). The transitions from $\mathrm{B}_{\mathrm{o} / \mathrm{m}}$ and from $\mathrm{E}_{\mathrm{o} / \mathrm{m}}$ modifica tions to the $\mathrm{C}$ form take place in the same range of tempera tures. Still, a significantly more energetic and sharper peak is characteristic for the $\mathrm{B}_{\mathrm{o} / \mathrm{m}} \rightarrow \mathrm{C}$ transformation than for the $\mathrm{E}_{\mathrm{o} / \mathrm{m}} \rightarrow \mathrm{C}$ one; for the latter, a broad peak is observed (Fig. 7b). The coincidence in temperature but not in energy among the $\mathrm{B}_{\mathrm{o} / \mathrm{m}}$ and $\mathrm{E}_{\mathrm{o} / \mathrm{m}}$ to $\mathrm{C}$ transitions can be explained in terms of their structures, since the transformation $\mathrm{B}_{\mathrm{o} / \mathrm{m}} \rightarrow \mathrm{C}$ involves a change in the molecular conformation of the $\mathrm{C}_{2} \mathrm{C}_{3}$ bond from gauche to all trans, which it is expected to need more energy than the transition from $\mathrm{E}_{\mathrm{o} / \mathrm{m}}$ to $\mathrm{C}$.

To conclude, $\mathrm{X}$ ray powder diffraction allows the identifica tion of the $\mathrm{C}$ and the triclinic forms $\left(\mathrm{A}_{\text {super }}\right.$ and $\left.\mathrm{A}_{2}\right)$. However, the identification of the $\mathrm{B}$ and $\mathrm{E}$ forms is not so straightfor ward, even more when mixtures of forms are present which is the most common case. In such cases, DSC analyses and infrared spectroscopy, as explained in the next subsection, are the way forward to distinguish between the $\mathrm{E}$ and the $\mathrm{B}$ forms.

\section{Infrared spectroscopy (FT-IR)}

The infrared spectra of the carboxylic acids show the char acteristic bands of the $n$ alkanes ${ }^{51}$ plus the bands caused by the vibrations of the carboxyl group (Table 9) and its interaction with the hydrocarbon chain. The vibration mode assignment is based on previous studies. ${ }^{28,30,52,53}$

By means of infrared spectroscopy with polycrystalline samples, the forms A and B can be identified and distinguished from $\mathrm{E}$ or $\mathrm{C}$, since there are characteristic bands associated with their specific molecular conformation. The different polytypes or triclinic modifications are only distinguishable by single crystal polarized infrared spectroscopy. Thus, the distinction between the polytypes and the modifications of the A form is disregarded in this section. Representative FT IR spectra of the $A_{2}, E_{m}, C$ and $B_{o}$ forms are shown in Fig. 8 .

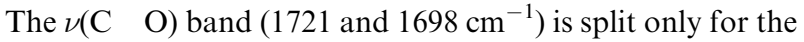
$\mathrm{B}$ form due to the chain tilt of the molecules within the unit cell that, together with the gauche conformation of the molecules, allows the carboxyl groups in neighbouring dimers to be close enough to interact. The $\delta\left(\mathrm{CH}_{2}\right)\left(1472 \mathrm{~cm}^{-1}\right)$ and the $r\left(\mathrm{CH}_{2}\right)$ $\left(718 \mathrm{~cm}^{-1}\right)$ bands are single bands for the A form, otherwise, the bands are split due to a different chain chain interaction of the molecules in the subcell. An exhaustive description of the different forms in terms of the subcell is found in ref. 54. For the matter of concern, the different triclinic A forms have a triclinic subcell, $\mathrm{T} \|$, with parallel molecules. Instead, the E, B and $\mathrm{C}$ forms have an orthorhombic subcell, $\mathrm{O} \perp$, with per pendicular molecules. Therefore, the different type of interac tion between the chains induces the splitting of the bands associated with the methylene group.

The $\omega\left(\mathrm{CH}_{2}\right)$ progression of bands (1320 $\left.1180 \mathrm{~cm}^{-1}\right)$ coupled with the carboxyl vibrations appears as a regularly spaced succession of bands for the structures with all trans molecules (E and C). The gauche conformation of the mole cules in the B form and the particular conformation of the molecules in the A forms cause strong interactions between the methylene and the carboxyl group, making the progression rather irregular. 

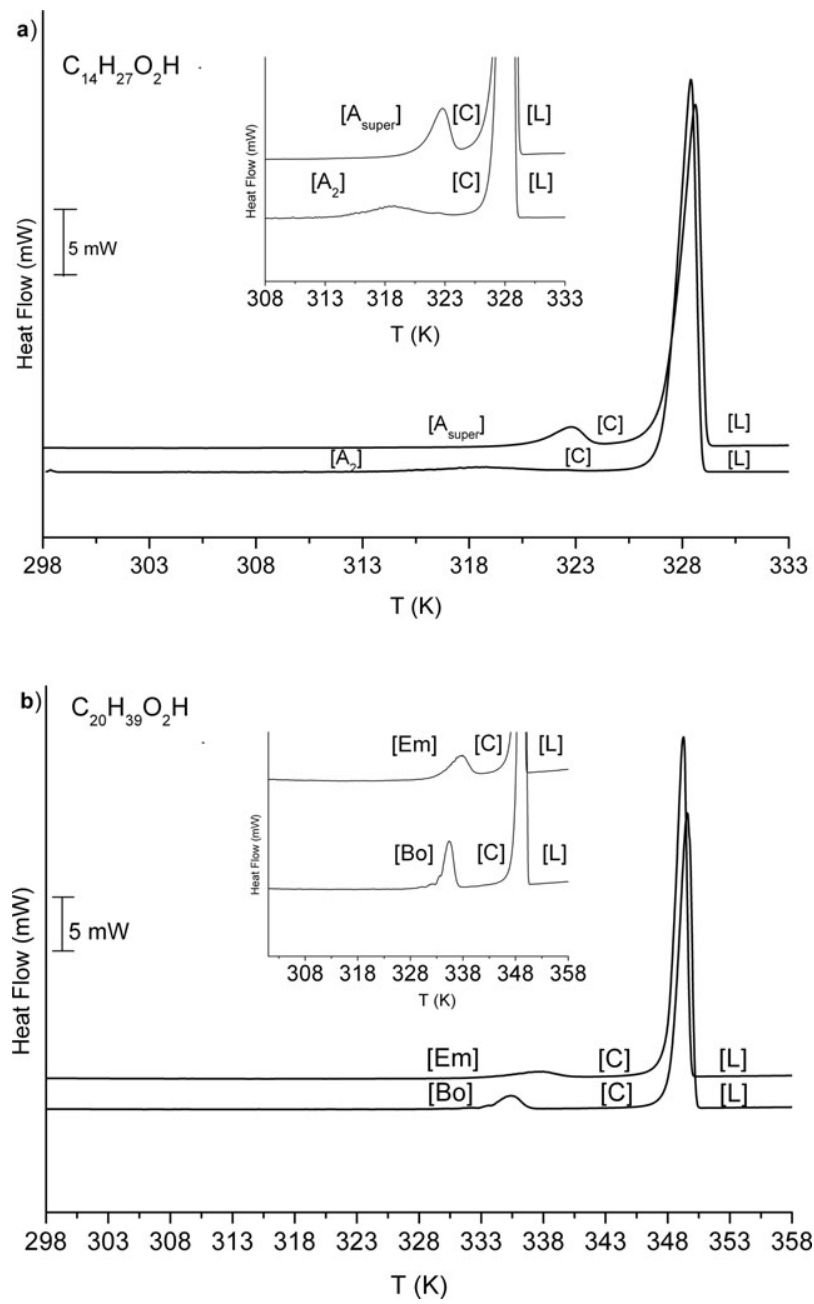

Fig. 7 DSC curves of (a) $\mathrm{A}_{2}$ and $\mathrm{A}_{\text {super }}$ forms of $\mathrm{C}_{14} \mathrm{H}_{27} \mathrm{O}_{2} \mathrm{H}$ and (b) $\mathrm{E}_{\mathrm{m}}$ and $\mathrm{B}_{\mathrm{o}}$ forms of $\mathrm{C}_{20} \mathrm{H}_{39} \mathrm{O}_{2} \mathrm{H}$ recorded at $2 \mathrm{~K}$ min ${ }^{1}$. Insets: expansions of the DSC curves close to the transition temperature.

The gauche conformation of molecules of the B form also affects the $\nu(\mathrm{C} \mathrm{C})$ vibrations $\left(11501000 \mathrm{~cm}^{-1}\right)$. The band at $1122 \mathrm{~cm}^{-1}$ is associated to the $\mathrm{C} \mathrm{C}$ stretching coupled with the carboxyl group whereas the band at $1098 \mathrm{~cm}^{-1}$ is associated to the coupling with the methyl terminal group showing for the $\mathrm{B}$ form a band at $1122 \mathrm{~cm}^{-1}$ significantly more intense than the one at $1098 \mathrm{~cm}^{-1}$. The relative intensities are inverted for the

Table 9 Most frequent vibrations of the carboxylic functional group as dimer

\begin{tabular}{|c|c|c|}
\hline Type of vibration & $\begin{array}{l}\text { Frequency/ } \\
\mathrm{cm} /\end{array}$ & Intensity \\
\hline $\mathrm{OH}$ stretching & $\approx 3000$ & Broad and strong \\
\hline $\begin{array}{l}\text { Overtone and combination } \\
\text { bands }\end{array}$ & 27002500 & Medium weak \\
\hline $\mathrm{C}=\mathrm{O}$ stretching asymmetric & 17401660 & $\begin{array}{l}\text { Broad and very } \\
\text { strong }\end{array}$ \\
\hline $\mathrm{C}=\mathrm{O}$ stretching symmetric & $1687 \quad 1625$ & Weak \\
\hline $\mathrm{C} \mathrm{OH}$ bending in plane & 14401395 & Medium \\
\hline C O stretching & 13151280 & Strong \\
\hline $\mathrm{O} \mathrm{H}$ bending out of plane & 960875 & Medium \\
\hline $\mathrm{OC}=\mathrm{O}$ & 690630 & Strong \\
\hline
\end{tabular}

a)

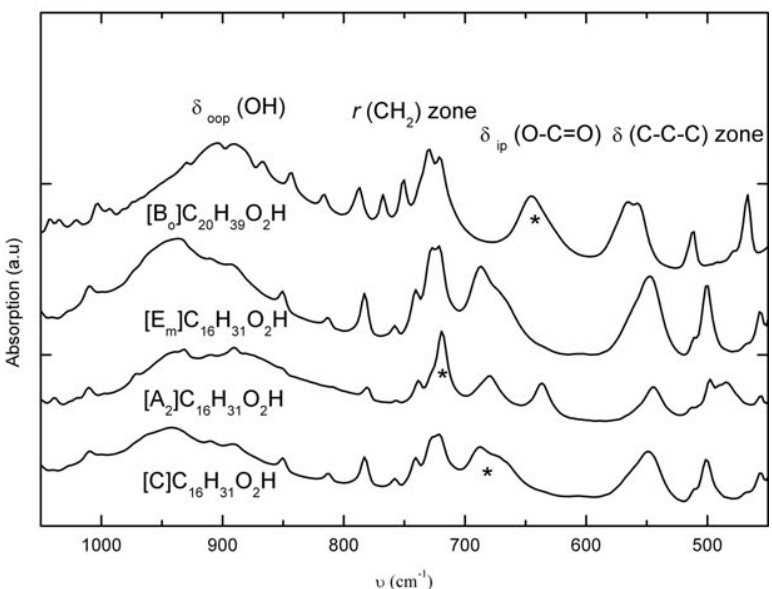

b)

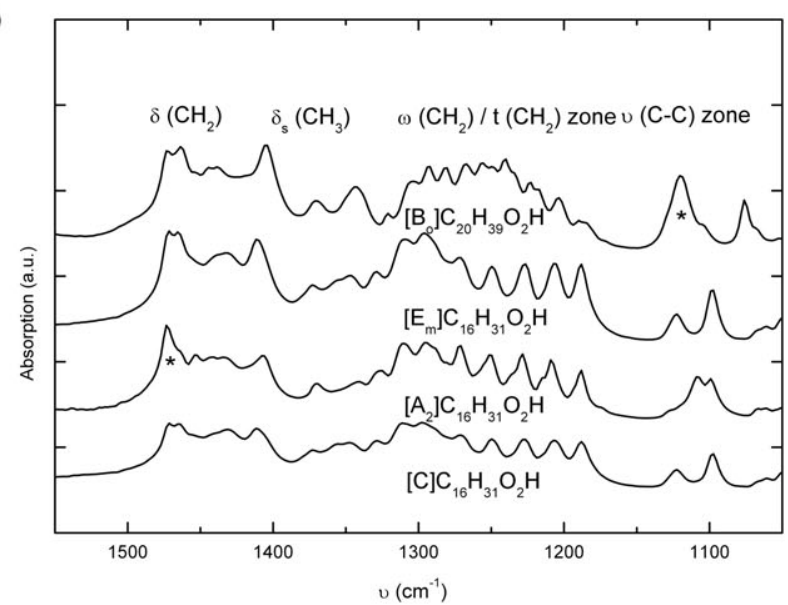

c)

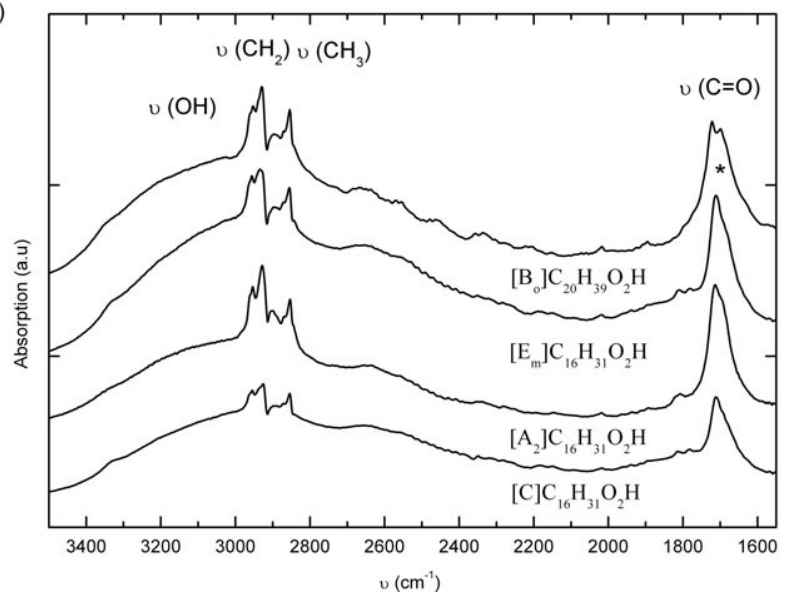

Fig. 8 Main zones of the infrared spectra at $298 \mathrm{~K}$ of $\mathrm{C}_{16} \mathrm{H}_{31} \mathrm{O}_{2} \mathrm{H}$ in $\mathrm{A}_{2}, \mathrm{E}_{\mathrm{m}}$ and $\mathrm{C}$ forms and of $\mathrm{C}_{20} \mathrm{H}_{39} \mathrm{O}_{2} \mathrm{H}$ in $\mathrm{B}_{\mathrm{o}}$ form. Asterisks indicate the most relevant bands to identify polymorphs.

$\mathrm{E}, \mathrm{C}$ and $\mathrm{A}$ forms. The unique band to distinguish the $\mathrm{E}$ and $\mathrm{C}$ forms is at the $\delta_{\text {oop }}(\mathrm{OH})$ zone $\left(960875 \mathrm{~cm}^{-1}\right)$, which is highly sensitive to the conformation of the polymethylene skeletal chain; broad single bands are found at $937 \mathrm{~cm}^{-1}$ and $941 \mathrm{~cm}^{-1}$ for the $\mathrm{E}$ and $\mathrm{C}$ forms, respectively. The $\delta_{\mathrm{ip}}(\mathrm{O} \quad \mathrm{C} \quad \mathrm{O})$ band is an intense single band at $645 \mathrm{~cm}^{-1}$ for the $\mathrm{B}$ form. The band is shifted to $686 \mathrm{~cm}^{-1}$ for the $\mathrm{E}$ form. A double band is observed for the triclinic forms at 683 and $638 \mathrm{~cm}^{-1}$, in agreement with 

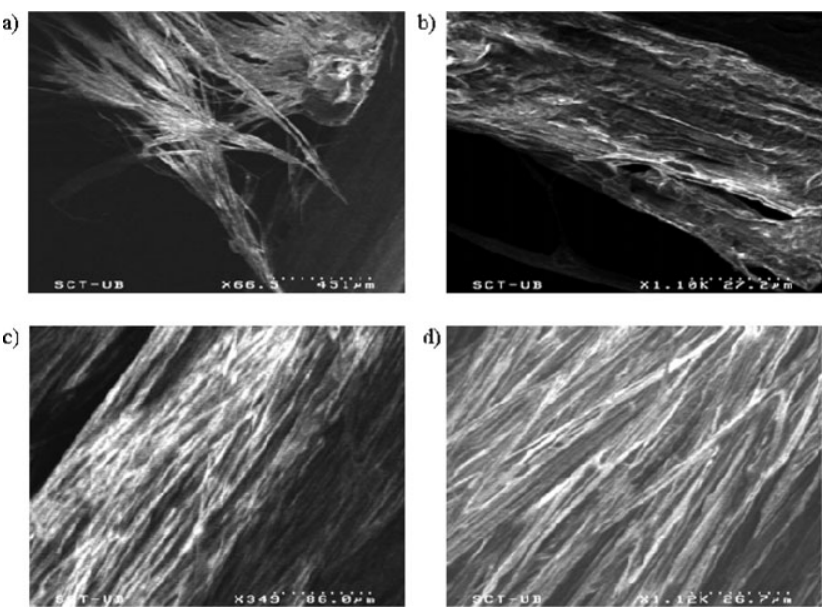

Fig. 9 SEM images of (a, b) $A_{2}$ and (c, d) $A_{\text {super }}$ forms of $\mathrm{C}_{14} \mathrm{H}_{27} \mathrm{O}_{2} \mathrm{H}$.

the two different molecular conformations in the triclinic structures. A broad double band at 688 and $668 \mathrm{~cm}^{-1}$ is assigned to a cis/trans tautomeric equilibrium exclusive of the $\mathrm{C}$ form that involves the transfer of a proton between the molecules of the dimer unit. ${ }^{55}$ The tautomeric equilibrium is only possible for the $\mathrm{C}$ form because of its suitable oxyge $\mathrm{n}$ oxygen distances of $2.62 \AA$. The proton transfer has not been observed in the other forms due to larger oxygen oxygen distances. $^{21-24}$

To summarize, FT IR spectroscopy is the proper technique to distinguish among the $\mathrm{E}$ and $\mathrm{B}$ forms and therefore it complements the information extracted from $\mathrm{X}$ ray powder diffraction data. It is also possible to identify the triclinic forms by means of this technique as has been explained.

\section{Scanning electron microscopy (SEM)}

Crystals of the $A_{2}$ form have needle like shape and dendritic growth (Fig. 9a). In a similar way, the $\mathrm{A}_{\text {super }}$ form crystallizes as long fibres (Fig. 9c). Images taken with greater magnifica tion show that the needle like crystals of the $A_{2}$ form (Fig. 9b)
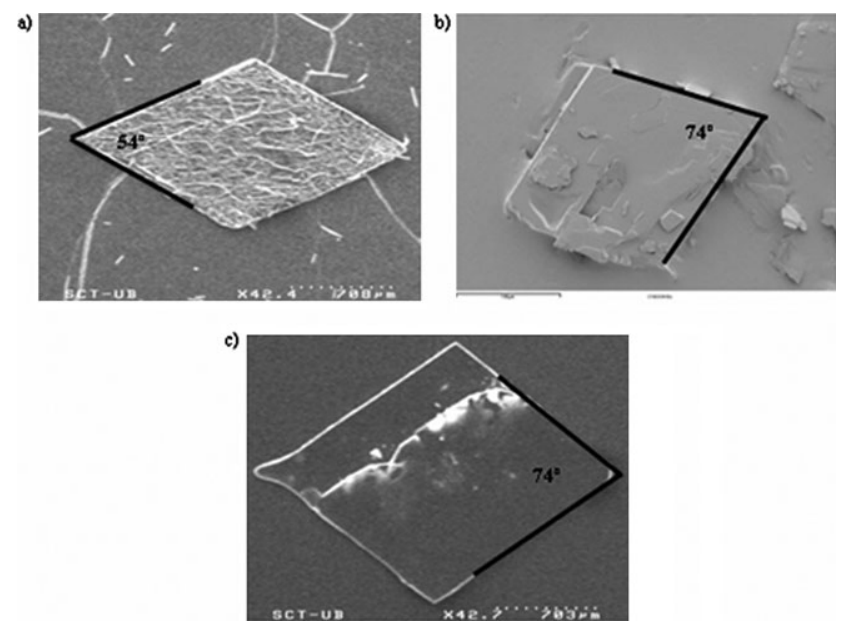

Fig. 10 SEM images of (a) a crystal of the $\mathrm{C}$ form of $\mathrm{C}_{16} \mathrm{H}_{31} \mathrm{O}_{2} \mathrm{H}$, (b) a crystal of the $\mathrm{E}$ form of $\mathrm{C}_{16} \mathrm{H}_{31} \mathrm{O}_{2} \mathrm{H}$, (c) a crystal of the $\mathrm{B}$ form of $\mathrm{C}_{18} \mathrm{H}_{35} \mathrm{O}_{2} \mathrm{H}$. have an irregular surface rather than the fibrous aspect of the $\mathrm{A}_{\text {super }}$ form (Fig. 9d), confirming the existence of two different types of triclinic structures as observed by powder $\mathrm{X}$ ray diffraction and DSC experiments.

Fig. 10a shows the plate like crystals with prismatic shape and an acute angle of around $54^{\circ}$, characteristic of the $\mathrm{C}$ form. Similar crystals with a larger acute angle (around $74^{\circ}$ ) are characteristic of the $\mathrm{E}_{\mathrm{o} / \mathrm{m}}$ (Fig. 10b) and the $\mathrm{B}_{\mathrm{o} / \mathrm{m}}$ forms (Fig. 10c). The structural similarities observed by $X$ ray powder diffraction analysis among the $\mathrm{B}$ and $\mathrm{E}$ forms agree with their identical morphology.

The $\mathrm{C}, \mathrm{B}_{\mathrm{o} / \mathrm{m}}$, and $\mathrm{E}_{\mathrm{o} / \mathrm{m}}$ forms, with plate like morphology, have the carboxyl groups and methyl groups in different terminal planes parallel to the $a b$ plane. This plane corre sponds to the faces with the lowest attachment energy, which developed slower and therefore have the most morphological importance. In the $\mathrm{A}_{\text {super }}$ form, each terminal plane contains both carboxyl and methyl terminal groups, which will cause strong hydrogen bond interactions along a direction rather than in a plane, giving rise to long fibres.

Moreover, when a mixture of forms was determined accord ing to $\mathrm{X}$ ray powder diffraction and DSC measurements, the individual morphologies were identified by SEM.

\section{Conclusions}

The DSC analyses on even saturated carboxylic acids reveal high enthalpies for the solid solid transition and especially for the solid liquid process. That makes saturated $n$ carboxylic acids and their alloys suitable candidates as molecular alloy phase change materials (MAPCM) to be used in the fields of energy storage and thermal protection.

The polymorphism of this family of compounds depends on the solvent used for crystallization, the temperature and the rate of crystallization, the purity and the parity of the acid. Triclinic forms predominate for acids with up to 14 carbon atoms, while monoclinic and orthorhombic forms (B, E and C) predominate for longer members of the family, in the range studied. Whatever the forms present at room temperature all of them transform irreversibly to the $\mathrm{C}$ form before melting, which is the stable form at high temperatures, the B form being the stable one at room temperature.

According to $\mathrm{X}$ ray powder diffraction, the forms $\mathrm{C}\left(P 2_{1} / a\right.$, $Z \quad 4), \mathrm{B}_{\mathrm{o}}(P b c a, Z \quad 8), \mathrm{B}_{\mathrm{m}}\left(P 2_{1} / a, Z \quad 4\right)$ and $\mathrm{E}_{\mathrm{m}}\left(P 2_{1} / a\right.$, $Z \quad 4$ ) are isostructural for the compounds studied herein, but the $\mathrm{C}, \mathrm{B}_{\mathrm{o}}, \mathrm{B}_{\mathrm{m}}$, and $\mathrm{E}_{\mathrm{m}}$ forms are not isostructural to each other.

The family of the $\left(\begin{array}{lll}0 & l\end{array}\right)$ reflections in the diffraction pattern is used to identify the $\mathrm{A}_{2}$, the $\mathrm{A}_{\text {super }}$ and the $\mathrm{C}$ forms. The $\mathrm{A}_{\text {super }}$ form gives further $(0 k l)$ and $(0 k \bar{l})$ reflections in this region. On the other hand, the middle angle region of the pattern provides the necessary information to distinguish among $\mathrm{B}$ and $\mathrm{E}$ forms and among their monoclinic and orthorhombic polytypes, as discussed in the text.

The infrared spectra recorded on polycrystalline samples show the characteristic bands due to molecules with a gauche conformation involving the $\mathrm{C}_{2} \quad \mathrm{C}_{3}$ bond characteristic for $\mathrm{B}_{\mathrm{o}}$ and $\mathrm{B}_{\mathrm{m}}$ forms as well as the intermediate conformation of the 
$\mathrm{C}_{1} \mathrm{C}_{2}$ bond of the triclinic forms. It is the most suitable technique to differentiate between the $\mathrm{B}_{\mathrm{o} / \mathrm{m}}$ and $\mathrm{E}_{\mathrm{o} / \mathrm{m}}$ forms.

SEM images confirm the high structural similarity between the $\mathrm{B}_{\mathrm{o} / \mathrm{m}}$ and $\mathrm{E}_{\mathrm{o} / \mathrm{m}}$ forms since both show exactly the same plate like crystals, while needle like crystals are observed for the $\mathrm{A}_{2}$ form and fibres for the $\mathrm{A}_{\text {super }}$ form.

\section{Acknowledgements}

We thank Dr Maria Barrio for her collaboration and scientific advice in the realization of the high pressure DSC measure ments and Silvia Miramunt for the experimental measure ments. We also thank the Ministerio de Ciencia y Tecnología for the financial support through the CICYT (grant: BES 2002 1855, project number: MAT2001 3352), the Generalitat de Catalunya through the Grup Consolidat (1996SGR0039), Xarxa Temàtica Aliatges Moleculars (20031XT 00077) and Centre de Referència en Materials Avançats per l'Energia (CeRMAE).

\section{References}

1 D. Mondieig, F. Rajabalee, V. Métivaud, H. A. J. Oonk and M. A. Cuevas Diarte, Chem. Mater., 2004, 16, 786.

2 V. Métivaud, V. A. Lefèvre, L. Ventolà, P. Négrier, E. Moreno, T. Calvet, D. Mondieig and M. A. Cuevas Diarte, Chem. Mater., $2005,17,3302$.

3 L. Ventolà, M. Ramírez, T. Calvet, X. Solans, M. A. Cuevas Diarte, P. Negrier, D. Mondieig, J. C. van Miltenburg and H. A. J. Oonk, Chem. Mater., 2002, 14, 508.

4 L. Ventolà, T. Calvet, M. A. Cuevas Diarte, H. A. J. Oonk and D. Mondieig, Phys. Chem. Chem. Phys., 2004, 6, 3726.

5 L. Ventolà, T. Calvet, M. A. Cuevas Diarte, V. Métivaud, D. Mondieig and H. A. J. Oonk, Mater. Res. Innovatations, 2002, 6, 284.

6 D. Mondieig, F. Rajabalee, A. Laprie, H. A. J. Oonk, T. Calvet and M. A. Cuevas Diarte, Transfus. Apher. Sci., 2003, 28, 143.

7 V. Métivaud, L. Ventolà, M. A. Cuevas Diarte, T. Calvet, D. Mondieig, IEA, ECES IA, Annex 17, 6th workshop, Arvika, Sweden, 89 June, 2004

8 E. von Sydow, Ark. Kemi., 1956, 9, 231.

9 K. Sato and M. Kobayashi, Crystals 13, Springer Verlag, Berlin, 1991.

10 M. Goto, Yukagaku, 1987, 36, 909.

11 G. Gbabode, P. Négrier, D. Mondieig, E. Moreno, T. Calvet and M. A. Cuevas Diarte, Chem. Eur. J., 2007, 13, 3150.

12 J. Bernstein, R. E. Davis, L. Shimoi and N. L. Chang, Angew. Chem., Int. Ed. Engl., 1995, 34, 1555.

13 T. R. Lomer, Acta Crystallogr., 1963, 16, 984.

14 M. Goto and E. Asada, Bull. Chem. Soc. Jpn., 1978, 51(1), 70.

15 M. Goto and E. Asada, Bull. Chem. Soc. Jpn., 1980, 53(8), 2111.

16 E. von Sydow, Acta Crystallogr., 1954, 7, 529.

17 E. von Sydow, Acta Crystallogr., 1955, 8, 845.

18 (a) E. von Sydow, Acta Crystallogr., 1954, 7, 823; (b) E. von Sydow, Acta Crystallogr., 1955, 8, 846.

19 M. Goto and E. Asada, Bull. Chem. Soc. Jpn., 1984, 57(4), 1145.
20 G. Gbabode, P. Négrier, D. Mondieig, J. M. Leger, E. Moreno, T. Calvet and M. A. Cuevas Diarte, Anal. Sci., 2006, 22(11), 269.

21 M. Goto and E. Asada, Bull. Chem. Soc. Jpn., 1978, 51(9), 2456.

22 F. Kaneko, H. Sakashita and M. Kobayshi, Acta Crystallogr., Sect. C: Cryst. Struct. Commun., 1994, C50, 245.

23 F. Kaneko, M. Kobayashi, Y. Kitagawa and Y. Matsuura, Acta Crystallogr., Sect. C: Cryst. Struct. Commun., 1990, C46, 1490.

24 F. Kaneko, H. Sakashita and M. Kobayshi, Acta Crystallogr., Sect. C: Cryst. Struct. Commun., 1994, C50, 247.

25 A. D. Bond, New J. Chem., 2004, 28(1), 104.

26 E. Moreno, R. Cordobilla, T. Calvet, M. A. Cuevas Diarte, F. J. Lahoz and A. I. Balana, Acta Crystallogr., Sect. C: Cryst. Struct. Commun., 2006, C62, 131.

27 V. Malta, G. Celotti, R. Zannetti and A. F. Martelli, J. Chem. Soc. $B, 1971,548$.

28 R. F. Holland and R. Nielsen, Acta Crystallogr., 1963, 16, 984.

29 E. von Sydow, Acta Chem. Scand. (1947 1973), 1956, 10, 1.

30 T. Kobayashi, M. Kobayashi and H. Tadokoro, Mol. Cryst. Liq. Cryst., 1984, 104, 193.

31 O. Masson and A. Ramponi, PEAKOC Program, Laboratoire de Matériaux Céramiques et Traitements de Surfaces, CNRS ENSCI, Limoges, France, 1996.

32 M. A. Neumann, J. Appl. Crystallogr., 2003, 36, 356.

33 MS Modeling (Materials Studio) $3.0 \mathrm{http}: / /$ www.accelrys.com/ mstudio/ms modeling/.

34 G. E. Engel, S. Wilke, K. D. M. Harrys and F. J. J. Leusen, J. Appl. Crystallogr., 1999, 32, 1169.

35 A. Boultif and D. Louer, J. Appl. Crystallogr., 1991, 24, 987.

36 J. Rodriguez Carvajal, FULLPROF Program, Laboratoire leon Brillouin, Paris, France, 1998.

37 N. Pingel, U. Poser and A. Wurflinger, J. Chem. Soc., Faraday Trans. 1, 1984, 80, 3221 .

38 G. L. Clark, Applied X Ray, McGraw Hill, New York, 1955.

39 E. Stenhagen and E. von Sydow, Ark. Kemi., 1952, 6(29), 309.

40 R. C. F. Schaake, J. C. van Miltenburg and C. G. de Kruif, J. Chem. Thermodyn., 1982, 14, 771.

41 N. Adriaansen, H. Dekker and J. Coops, Recl. Trav. Chim. Pays Bas, 1964, 83(6), 557.

42 W. Beckman, R. Boistelle and K. Sato, J. Chem. Eng. Data, 1984, 29, 211.

43 K. Sato, K. Suzuki, M. Okada and N. Garti, J. Cryst. Growth, 1985, 72, 699.

44 K. Sato and R. Boistelle, J. Cryst. Growth, 1984, 66, 441.

45 K. Sato and R. Boistelle, J. Colloid Interface Sci., 1983, 94, 593.

46 A. Wurflinger and G. M. Schneider, Ber. Bunsen Ges. Phys. Chem., 1973, 77, 121

47 H. Sun, J. Phys. Chem. B, 1998, 102, 7338.

48 A. Gavezzotti and G. Filippini, Theoretical Aspects and Computer modeling, J. Wiley and Sons, Chichester, 1997, ch. 3, pp. 6197.

49 V. Vand, W. M. Morley and T. R. Lomer, Acta Crystallogr., 1951, 4, 324.

50 S. Abrahamsson and E. von Sydow, Acta Crystallogr., 1954, 7, 591.

51 (a) J. H. Schachtschneider and R. G. Snyder, Spectrochim. Acta, 1963, 19, 85; (b) J. H. Schachtschneider and R. G. Snyder, Spectro chim. Acta, 1963, 19, 117.

52 R. F. Holland and J. Nielsen, J. Mol. Spectrosc., 1962, 9, 436.

53 F. Kaneko, K. Tashiro and M. Kobayashi, J. Cryst. Growth, 1999, 198, 1352.

54 N. Garti and K. Sato, Crystallization and polymorphism of fats and fatty acids, Marcel Dekker Inc., New York, 1988.

55 S. Hayashi and J. Umemura, J. Chem. Phys., 1975, 63, 1732. 